\title{
Global Trade Flows: Revisiting the Exchange Rate Elasticities
}

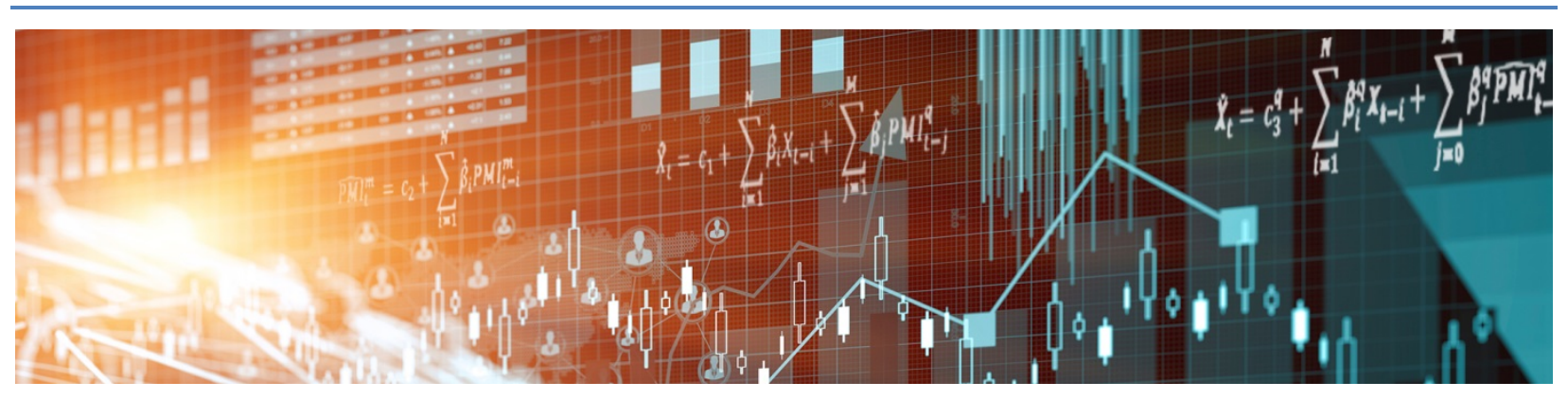

by Matthieu Bussière, Guillaume Gaulier and Walter Steingress 
Bank of Canada Staff Working Paper 2017-41

September 2017

\title{
Global Trade Flows: Revisiting the Exchange Rate Elasticities
}

\author{
by \\ Matthieu Bussière ${ }^{1}$ \\ Guillaume Gaulier ${ }^{2}$ \\ Walter Steingress ${ }^{3}$ \\ 1 Banque de France \\ mattheiu.bussiere@banque-france.fr \\ 2 Banque de France \\ guillaume.gaulier@banque-france.fr \\ 3 International Economic Analysis Department \\ Bank of Canada \\ Ottawa, Ontario, Canada K1A OG9 \\ walter.steingress@bankofcanada.ca
}




\section{Acknowledgements}

We would like to thank Olivier Blanchard, Meredith Crowley, Linda Goldberg, Jean Imbs, Oleg Itskhoki, Oleksiy Kryvstov, Philippe Martin, Thierry Mayer, Isabelle Méjean, Kadee Russ, Cyrille Schwellnus, Vincent Vicard and seminar participants at the Deutsche Bundesbank, the Banque de France, the Bank of Canada, Michigan State University and the Paris School of Economics for helpful comments and discussions. 


\begin{abstract}
This paper contributes to the debate on the magnitude of exchange rate elasticities by providing a set of price and quantity elasticities for 51 advanced and emerging-market economies. Specifically, for each of these countries we report the elasticity of trade prices and trade quantities on both the export and on the import sides, as well as the reaction of the trade balance. To that end, we use a large unified database of highly disaggregated bilateral trade flows, covering 5,000 products and more than 160 trading partners. We present a range of estimates using not only standard regression techniques but also generated regressors that aim to address key omitted variable biases, particularly relating to unobserved marginal costs and competitor prices in the importing market. Our results show that quantity elasticities are significantly below one, pass-through is incomplete and export prices react significantly to exchange rate changes. Despite low quantity elasticities, the trade balance reacts positively to a depreciation in all countries because export and import prices adjust. Overall, our findings suggest that changes in the exchange rate can play an important role in addressing global trade imbalances.
\end{abstract}

Bank topic(s): Exchange rates; Inflation and prices; International topics

JEL code(s): C51, F14, F31, F33, F41

\title{
Résumé
}

Cet article contribue au débat sur l'ordre de grandeur des élasticités commerce en fournissant les élasticités prix et quantités de 51 pays avancés et émergents. Plus particulièrement, nous présentons pour chacun de ces pays l'élasticité des prix et des quantités au taux de change pour les exportations et pour les importations, ainsi que la réaction de la balance commerciale. À cette fin, nous utilisons des données très désagrégées de commerce bilatéral couvrant 5000 produits différents et plus de 160 pays partenaires. Nous présentons une gamme de résultats obtenus à la fois au moyen de régressions classiques et de régresseurs générés qui prennent en compte l'effet de variables non observées, notamment les coûts marginaux et le prix des compétiteurs dans le pays importateur. Ces résultats montrent que les élasticités quantités sont significativement inférieures à un, que la transmission des variations du taux de change est incomplète et que les prix d'exports réagissent significativement aux mouvements du taux de change. Malgré des élasticités quantités faibles, la réaction de la balance commerciale à une dépréciation est positive pour tous les pays parce que les prix d'imports et d'exports s'ajustent. Dans l'ensemble, les résultats donnent à penser que les taux de change peuvent jouer un rôle important dans la correction des balances commerciales.

Sujet(s) : Taux de change; Inflation et prix; Questions internationales

Code(s) JEL : C51, F14, F31, F33, F41 


\section{Non-technical summary}

The aim of the present paper is to provide exchange rate elasticities (covering both prices and quantities on the export and on the import sides) for 51 countries, of which 26 are emerging markets and 25 are advanced economies. For this purpose, we use a very rich database of bilateral trade flows covering 5,000 products. This database allows us to address important biases that arise in the context of such regressions, particularly relating to unobserved marginal costs and competitor prices in the import market. Marginal costs may indeed be correlated with exchange rate movements because exports typically have high import content: the ceteris paribus loss in competitiveness that arises from an appreciation of the exchange rate can be partly offset by the fact that it lowers the cost of imported inputs. Against this background, incomplete pass-through may stem either from changing profit margins or varying production costs. Another important factor that we address in the enhanced specification is the reaction of competitor prices in the importing market resulting from strategic complementarities in pricing.

The contribution of the paper is therefore twofold. First, this is to our knowledge the only paper that presents a complete set of exchange rate elasticities for 51 countries, covering export prices, export volumes, import prices and import volumes. These results allow us to derive the reaction of the trade balance following a change in the exchange rate and check whether the Marshall-Lerner conditions hold. Second, this paper explores the role of unobserved variables such as, for the price equations, marginal costs and competitor prices in the importing market, and for the volume equations other supply and demand factors not captured by GDP changes.

The main empirical results in this paper can be summarized as follows. First, our baseline estimates indicate that exchange rate pass-through is incomplete for most countries and that there is substantial heterogeneity in the reaction of export and import prices across countries. The estimates indicate that, on average, the elasticity of export prices to exchange rate changes is higher in advanced economies than in emerging markets, suggesting that exporters from emerging-market economies have more market power than their counterparts in advanced economies. On the other hand, for import prices we do not find significant differences between the two groups of countries. Second, our baseline quantity regressions yield exchange rate elasticities in the ballpark of $0.2-0.4$ (depending on how the aggregate results are calculated), implying price elasticities around 0.5. Third, based on the estimated price and quantity exchange rate elasticities, we find that the Marshall-Lerner conditions are satisfied for all countries in the sample. This is largely because pass-through is incomplete in the majority of countries, while export prices in the producer (exporter) currency react significantly to exchange rate changes. As a result, the full MarshallLerner conditions are satisfied even though some of the exchange rate trade quantity elasticities are not significantly different from zero.

Fourth, once we control for time varying country and product fixed effects, the median exchange rate passthrough coefficient for exports increases to $87 \%$ (from $65 \%$ in the baseline). One possible interpretation is that this alternative specification controls for marginal costs and therefore focuses on the reaction of profit margins only, suggesting that a significant part of the reaction of export prices in producer currency comes from varying costs (associated, e.g., with import costs). In the import price equation, the alternative specification controls for time varying conditions in the importing countries, and in particular local prices. This alternative specification also reduces the pass-through coefficient compared with the baseline (as foreign exporters take into account the reaction of local prices). Generally, turning to the fixed-effects equations reduces the dispersion of the coefficients, suggesting that controlling for unobserved variables removes a substantial source of cross-country heterogeneity.

Overall, these different specifications yield complementary insights on the issue of exchange rate elasticities. While the baseline specification is very close in spirit to the macro approach (the magnitude of these elasticities being correlated with existing macro studies), the fixed-effect approach goes one step further and helps disentangle the different mechanisms at work when the exchange rate varies. From a policy perspective, the results suggest that exchange rate movements can play an important role in addressing global trade imbalances. 


\section{Introduction}

The large exchange rate movements recorded in recent years have reignited the debate on the effect of exchange rate movements on trade flows and global imbalances. Prominent observers have expressed concerns that large currency depreciations in key economies may have an effect on their own country's competitiveness and raised the fear of "currency wars" across countries (Mantega (2010)). Meanwhile, the effect of exchange rate changes on domestic prices (exchange rate pass-through) is a factor that receives significant attention among central bankers, as witnessed for instance by recent speeches by Yellen (2015), Fischer (2015), or Forbes (2015). In spite of the prevalence of these questions in the policy debate, few papers present a range of trade elasticities across countries (see for example Bussière et al. (2014), Gopinath (2015) and Leigh et al. (2015)). In fact, there is still a debate in the existing literature on how to estimate such elasticities and whether "elasticity pessimism" (Orcutt (1950)) or "elasticity optimism" (Imbs and Méjean (2015)) should prevail. ${ }^{1}$

The aim of the present paper is to contribute to the debate on the magnitude of exchange rate elasticities by providing country-specific price and quantity elasticities for the export as well as for the import side. ${ }^{2}$ For this purpose, we use a very rich database of bilateral trade flows, disaggregated at the six-digit level and covering 5,000 products. As a first step, we estimate country-specific exchange rate elasticities for prices and quantities and calculate the implied effect on the trade balance, i.e., verifying the Marshall-Lerner conditions. Our results show that the trade balance improves significantly following an exchange rate depreciation, particularly for smaller and more open economies. Quantity elasticities are low in almost all countries.

In a second step, we exploit the structure of our data set and uncover underlying factors determining price and quantity elasticities. The magnitude of the estimated elasticties crucially depends on the extent to which the exchange rate is correlated with unobserved marginal costs and competitor prices in the importing market. Marginal costs may indeed be correlated with exchange rate changes because exports typically have a strong import content, see Ossa (2015): the ceteris paribus loss in competitiveness that arises from an appreciation of the exchange rate, for instance, can be partly offset by the fact that it lowers the cost of imported inputs. We can capture the correlation between marginal costs and the exchange rate with time-varying country and product fixed effects. Our data set also allows us to control for the reaction of competitor prices in the import market. When the exchange rate of the exporting country appreciates, for instance, exporters can reduce the level of pass-through by lowering prices in their currency (Amiti et al. (2016)). The extent to which this adjustment is needed depends on whether local competitors in the import market raise their prices (responding to a depreciation of their currency).

Going one step further, we apply the idea of Pagan (1984) and use product fixed effects as generated regressors to simultaneously control for both unobserved variables within the same regression. Similar to Schmalensee and Joskow (1986), Baker and Fortin (2001) and Redding and Venables (2004), we first proxy unobserved marginal costs with a generated regressor from a fixed-effect regression. In the second step, we use the generated regressor obtained from the first step as an explanatory variable in the estimation of the exchange rate pass-through. The main finding of our approach is that exchange rate elasticities change considerably once we proxy for unobserved marginal costs and competitor prices. However, these changes reflect the fact that the economic interpretation that we give to the coefficients is radically different once country-specific time-varying fixed effects are introduced in the regressions. For instance, in the export price regression, adding these fixed effects removes a substantial source of variation of export prices (in the exporter's currency). The elasticities we estimate are therefore complementary to the macroeconomic elasticities obtained from standard regressions as the rich structure of our data set allows us to

\footnotetext{
1"Elasticity pessimism" postulates that trade elastricities are small and changes in relative prices have little impact on the trade balance. "Elasticity optimism" advocates that estimates of aggregate trade elasticities are biased downwards because sectoral heterogeneity is not taken into account when using macroeconomic data. Industries with inelastic demand receive a disproportionately high weight in the aggregate measure.

${ }^{2}$ The list of countries includes 26 emerging markets and 25 advanced economies and broadly corresponds to that of the IMF External Balance Assessment (EBA); see full list of countries in Table 1.
} 
uncover the key mechanisms at play when the exchange rate varies.

The main estimation results in this paper can be summarized as follows. First, the baseline regressions suggest that pass-through is incomplete: a $10 \%$ nominal depreciation would be associated with a $4.8 \%$ rise in import prices (in local currency). This number corresponds to the median across countries but hides substantial heterogeneity. ${ }^{3}$ For instance, we find that exchange rate pass-though is much lower than the median in the United States (30\%) but much higher in Turkey (80\%) or Japan (87\%). In large European countries such as France, Germany, Italy or the United Kingdom the level of pass-though is close to the median. ${ }^{4}$ Consistent with our result of incomplete pass-through to import prices, we find that export prices in producer currencies react significantly to exchange rate changes, especially for emerging-market economies. This reaction of export prices to a change in the exchange rate contributes to an improvement of the trade balance following a depreciation. ${ }^{5}$ We also find that the reaction of export prices is positively correlated with that of import prices: the countries that have high exchange rate passthrough to import prices also tend to adjust their export prices significantly. This is either because the determinants of these elasticities are the same or because imports are used as intermediate inputs (so the countries that have high pass-through can adjust export prices to a greater extent), a point that the alternative specification allows us to explore further.

Second, export and import quantities also react to exchange rate changes. The median elasticities of the baseline regressions are in the range of $0.2-0.4$. Yet, for the two quantity equations there is significant heterogeneity across countries, especially for the import quantity equation. Indeed, for many countries the coefficient of the exchange rate in this regression is not significantly different from zero. Building on the reaction of export and import prices and quantities, we can derive the overall reaction of the trade balance, taking the example of the 2012 trade balance as a starting point. Overall, the results suggest that a $10 \%$ nominal depreciation would be associated with a change in the trade balance of about $2 \%$ of GDP (towards a higher surplus or lower deficit). Heterogeneity for the estimated elasticities of export and import quantities and prices, and especially the degree of trade openness, translate into significant heterogeneity of trade balance response across countries: while some countries see a small change in their trade balance (notably Japan, the United States, and Norway), others are estimated to experience much larger changes (in particular Hong Kong, Ireland, and Costa Rica, reflecting, to a large extent, their high openness to trade). Overall, we find that the Marshall-Lerner conditions hold for all countries: following a depreciation, the trade balance improves for all of them. This is largely because we consider here the full Marshall-Lerner conditions, i.e., taking into account not just the sum of the export and import quantity elasticities, but also the reaction of export and import prices. To the extent that exchange rate pass-through is incomplete in most countries, and that export prices in the producer (exporter) currency react significantly to exchange rate changes, this substantially contributes to the overall improvement of the trade balance.

The third set of results stems from our alternative regressions. Controlling for time-varying country and product fixed effects substantially modifies the results and their interpretations. For export prices, the median exchange rate pass-through coefficient increases to $87 \%$ (from $65 \%$ in the baseline). One interpretation is that this alternative specification controls for marginal costs and therefore focuses on the reaction of profit margins only, suggesting that a significant part of the reaction of export prices in producer currency comes from varying costs (associated, e.g., with import costs). In the import price equation, the alternative specification controls for timevarying conditions in the importing countries, and in particular local prices. This alternative specification reduces the pass-through coefficient compared with the baseline (as foreign exporters take into account the reaction of local

\footnotetext{
${ }^{3}$ In Table 2 and Table 3 we report other key statistics such as the simple mean, a weighted mean using the relative size of nominal exports and imports, as well as the standard deviation of the coefficients across countries. In Section 4 we comment on selected country-specific results and compare aggregate elasticities between advanced and emerging-market economies.

${ }^{4}$ The coefficients that we estimated in the baseline regression for export and import prices are positively correlated with existing studies, as explained in Section 4.

${ }^{5}$ Note that our specifications are symmetric and linear, so an appreciation is expected to have the same effect as a depreciation, with the opposite sign.
} 
prices). Generally, turning to the fixed-effects equations reduces the dispersion of the coefficients, suggesting that controlling for unobserved variables removes a substantial source of cross-country heterogeneity. Finally, a two-step approach yields coefficients that are again different, reflecting the differences introduced in each of the two steps. The implied average response of the trade balance following an exchange rate shock using the new set of elasticies increases significantly compared to the baseline. However, the cross-country ranking in terms of magnitude of the effect remains broadly unchanged.

Overall, the different specifications we explore yield complementary insights on exchange rate elasticities. While the baseline specification is very close in spirit to the standard macro approach (the magnitude of these elasticities being correlated with existing macro studies), the fixed-effects approach goes one step further and helps us disentangle the different mechanisms at work when the exchange rate varies. From a policy perspective, the results suggest that exchange rate changes can play an important role in addressing global trade imbalances.

Our paper relates to the existing literature in the following way. Empirical research on exchange rate elasticities is often separated into two distinct approaches: the macro and the micro approaches. Papers following the macro approach (Leigh et al. (2015), Bussière et al. (2014) for pass-through) estimate the response of aggregate exports and imports to changes in the aggregate price index, like the real effective exchange rate, following mostly a time series analysis for a particular country, or using panel data. By contrast, the micro approach (Gaulier et al. (2008), Ruhl (2008), Feenstra et al. (2014), Fitzgerald and Haller (2014), Imbs and Méjean (2015) and Bas et al. (2017)) focuses on the bilateral variation in trade and relative price differences across countries at different levels of aggregation (firm or sectoral level). Similarly, this paper exploits the bilateral variation of prices and quantities and shows that the obtained elasticities are comparable to the macro elasticities and aggregation biases between bilateral and aggregate time series are small. Furthermore, to the best of our knowledge, this is the only paper that presents a complete set of exchange rate elasticities for a large number of countries, covering export prices, export quantities, import prices and import quantities within a unified approach. Our elasticities are comparable across countries, allowing us to draw implications for model parameters in aggregate pricing models and to derive the reaction of the trade balance following a change in the exchange rate, i.e., checking whether the Marshall-Lerner conditions hold.

In general, empirical papers on the transmission of exchange rate shocks into prices and quantities are based on the export pricing models going back to Krugman (1986) and Knetter (1989). The underlying mechanisms, like firm heterogeneity (Atkeson and Burstein (2008) and Berman et al. (2012)), distribution costs (Corsetti and Dedola (2005)), the importance of trade integration (Auer (2015)), the import intensity of exports (Amiti et al. (2014)), strategic complementarities (Amiti et al. (2016)), market structure (Amiti et al. (2016) and Auer and Schoenle (2016)), the lack of information about competitors (Garetto (2016)) as well as the choice of the invoicing currency (Devereux et al. (2015) and Gopinath (2015)), are key in order to understand the aggregate response of exchange rate shocks. While this paper does not directly identify the channels at work, it shows that the estimation of aggregate exchange rate elasticities can be severely biased if the underlying mechanism is correlated with the exchange rate and not taken into account. For example, if firms participate in global value chains, their exported products will contain intermediate inputs from abroad. As a result, any change in the exchange rate will affect their marginal costs and their optimal export prices. Similarly, if firms have to maintain a distribution network or change their export price due to competitor price changes in the importing destination, markups will be correlated with the exchange rate and thus affect the optimal pricing decision with respect to the exchange rate. We address this correlation by exploiting the panel structure of the data set and introducing time-varying country and product fixed effects and generated regressors as proxies for unobserved omitted variables. This makes it possible to offer new insights on the determinants of aggregate exchange rate pass-through and trade elasticities.

The rest of the paper is organized as follows. Section 2 explains the theoretical framework and derives the corresponding estimation equations. Section 3 discusses our empirical strategy. The main results and their interpretations are presented in Section 4. Section 5 provides robustness tests and further results. Section 6 
concludes.

\section{Theoretical framework}

Complete exchange rate pass-through implies that import prices (expressed in the importer's currency) move one to one with changes in the exchange rate, while movements in export prices (expressed in the exporter's currency) are insensitive to currency changes. At the other extreme, exporters could reduce pass-through to zero if they decided to (and could) offset all changes in the exchange rate by adjusting their prices in the exporter's currency. In practice, pass-through estimates are generally between zero and one. This section explains what may affect the degree of exchange rate pass-through.

\subsection{Pricing decision of firms}

Before presenting the estimation equations, we discuss the pricing decision of exporting firms in different destination markets. We start with a very general accounting framework that is common to most of the pass-through models, see Amiti et al. (2016). Based on this framework, we will derive the estimation equation under general demand and cost structures. Define the export price (fob) that an exporting firm from country $i$ of product $k$ to destination $j$ charges in destination $j$ in importer currency as $p_{i j k t}$ :

$$
p_{i j k t}=\frac{\theta_{i j k t} m c_{i k t}}{s_{i j t}},
$$

where $\theta_{i j k t}$ is the markup that a firm of exporting country $i$ in the product class $k$ charges in importing country $j$ at time $t$. $m c_{i k t}$ is the marginal cost in the producer's currency, which is assumed to be the same across all destination markets $j . \quad s_{i j t}$ is the bilateral exchange rate between exporter $i$ and importer $j$ denominated in country $i$ 's currency per unit of country $j$ 's. ${ }^{6}$ Note that the markup specification is very general and allowed to be different in each destination for every product. The corresponding import price (cif) expressed in importer's currency is

$$
p_{i j k t}=\frac{\theta_{i j k t} \tau_{i j k} m c_{i k t}}{s_{i j t}},
$$

where $\tau_{i j k}$ are bilateral product-specific trade costs which are assumed to be time invariant. The corresponding import price is the equivalent to the export price if we account for the exchange rate changes between the importer's and the exporter's exchange rate. This general pricing equation relies on two basic assumptions, see Amiti et al. (2016): (1) the demand is invertible and (2) firms are static profit maximizers under full information, which excludes any form of dynamic price-setting considerations. From now on, we assume that these two assumptions are satisfied. However, note that the pricing decision in equation 2 does not depend on the nature of market competition, i.e., allowing for both monopolistic and oligopolistic competition. As a result, we can write the estimation equation of the exchange rate pass-through on export prices in the importer's currency of country $[i]$ as

$$
d \log \left(p_{[i] j k t}\right)=\alpha_{[i]}-\beta_{1,[i]} d \log \left(s_{i j t}\right)+\beta_{2,[i]} d \log \left(\theta_{i j k t}\right)+\beta_{3,[i]} d \log \left(m c_{i k t}\right)+e_{i j k t} .
$$

The variable of interest in equation 3 is $\beta_{1,[i]}$. If we could observe markups $\left(\theta_{i j k t}\right)$ and marginal costs $\left(m c_{i k t}\right)$, all the coefficients in equation 3 should be one. Empirical difficulties arise due to the fact that $\theta_{i j k t}$ and $m c_{i k t}$ are usually unobserved and potentially correlated with the exchange rate, which is why pass-through might be incomplete. Concerning the interpretation of the estimated coefficient $\hat{\beta}_{1,[i]}$, in the case of complete pass-through, i.e., when the exchange rate depreciates $\left(d s_{i j t}>0\right)$, the exchange rate change is completely passed on to import

\footnotetext{
${ }^{6}$ Given this definition of exchange rates, an increase in $s_{i j t}$ implies a depreciation of country $i$ 's currency, which improves its competitiveness in foreign markets.
} 
prices, $\hat{\beta}_{1,[i]}=1$, and the export price in the exporter's currency does not change. On the other hand, if the exporter changes the export price one to one with the exchange rate in order to keep the price in the importing country constant, the pass-through coefficient is $\hat{\beta}_{1,[i]}=0$. Generally, it may be optimal for the exporter to change the export price only partly with the exchange rate (i.e., incomplete pass-through). In this case the pass-through

coefficient lies between zero and one $\left(0 \leq \hat{\beta}_{1,[i]} \leq 1\right)$. Next, we discuss the potential reasons why marginal costs and markups are potentially correlated with the exchange rate.

\subsubsection{Marginal costs}

In general, marginal costs will be correlated with the exchange rate if exporters buy their intermediate goods from abroad. Based on the detailed firm-level data from Belgium, Amiti et al. (2014) show that large exporting firms are simultaneously large importing firms and that these firms basically determine the aggregate pass-through. Due to the reliance on intermediate imports, marginal costs of production will depend on the exchange rate shocks and change the optimal pricing decision of exports. In particular, firms' marginal costs, $m c_{i k t}$, will be positively correlated with the exchange rate, $\operatorname{Corr}\left(d \log m c_{i k t}, d \log s_{i j t}\right)>0$, because a depreciation of the exporter's exchange rate $\left(s_{i j t} \uparrow\right)$ increases the marginal costs in terms of local currency. With respect to the direction of the bias, we expect that accounting for the international input-output linkages of firms will increase the exchange rate passthrough. As Amiti et al. (2014) show, large import-intensive firms have high export market shares and hence set high export markups. These high markups act as a buffer for the exchange rate fluctuations and will limit the effect of exchange rate shocks on export prices.

On a more macroeconomic scale, exchange rate fluctuations can have a direct impact on wages and thus alter marginal costs of firms through several other channels. First, an exchange rate depreciation increases the consumer price index and reduces real wages. At the same time, the depreciation may also change inflation expectations and thus affect the wage-setting mechanism. Second, an exchange rate depreciation increases competitiveness and may increase domestic production, which leads to higher labor demand and wages, see Campa and Goldberg (2001). Third, exchange rate fluctuations may also have a direct impact on domestic labor supply through migration by changing the relative wages across countries, see Mishra and Spilimbergo (2011) for empirical evidence.

\subsubsection{Strategic complementarities in price setting}

Markups, $\theta_{i j k t}$, are also likely to adjust with the exchange rate. One reason is that firms have to pay distribution costs in the destination country, see Corsetti and Dedola (2005) and Berman et al. (2012). In this case, the pricing decision of the exporter and thus the markup, $\theta_{i j k t}$, is a function of the distribution cost, $\eta_{j k t}$. This distribution cost has to be paid in the importer's currency. Therefore, any change in the bilateral exchange rate will change the distribution costs and the optimal pricing decision of the exporter. In particular, an appreciation of the importer's currency, which is equivalent to a depreciation of the exporter's currency $\left(s_{i j t} \uparrow\right)$, increases the distribution cost in the importing destination $j, \operatorname{Corr}\left(d \log \eta_{j k t}, d \log s_{i j t}\right)>0$ and forces the firm to reduce its markup, $\operatorname{Corr}\left(d \log \theta_{i j k t}, d \log s_{i j t}\right)<0$.

An alternative explanation, highlighted by Amiti et al. (2016), relates to strategic complementarities in price setting, where exporters adjust their prices due to changes in competitors' prices in the importing country. Consider the following example. Suppose there is a currency crisis in the importing country and its currency depreciates, which is equivalent to a appreciation of the exporter's currency $\left(s_{i j t} \downarrow\right)$. If pass-through is not zero, the exporter does not absorb the full currency change, and the exporter's price in terms of the importer's currency will increase. In oligopolistic markets, the presence of strategic complementarities in price setting implies that competing firms in the importing country will raise their prices as well, which leads to a further reaction of the exporter and so on until the equilibrium is reached. As a result, exporter's will raise their export price by more than in the absence of strategic complementarities and the observed import pass-through is amplified. Overall, we have 
a negative correlation between the exchange rate, competitors' prices in the importing destination $\left(p_{-j k t}\right)$, i.e., $\operatorname{Corr}\left(d \log p_{-j k t}, d \log s_{i j t}\right)<0$.

In both cases, we have an omitted variable bias that implies a higher observed pass-through if we do not control for changes in export prices due to (1) changes in distribution costs or (2) changes of competitors' prices in the importing country. For this reason, we include importer fixed effects in the empirical specification and expect to observe a lower pass-through compared to the case without importer fixed effects. Next, we present the estimation equation with the empirical specifications.

\section{Empirical analysis}

The empirical trade literature often faces a trade-off between sectoral disaggregation, country coverage and data frequency. Bussière et al. (2014), for example, use data on import and export prices at the country level on quarterly frequency. The main drawback of the macro data is that they might be subject to aggregation bias. ${ }^{7}$ As a result, aggregate prices make pass-through estimates difficult to discriminate between incomplete pass-through reflecting price discrimination and incomplete pass-through reflecting changes in quality. On the other hand, the product-level data used in this paper allows for a rich set of fixed effects that minimize the aggregation bias and partly control for product differentiation issues. Moreover, with the exception of Bussière et al. (2014), in most existing aggregate studies empirical evidence exists only for a small number of advanced economies.

Our analysis is based on the BACI database developed by the CEPII, see Gaulier and Zignago (2010), which is based on the United Nations COMTRADE database. The data are harmonized in order to reconcile export and import declaration of values and quantities across countries, where precedence is given to countries with more reliable trade statistics. The main advantage of this database is that it has an extensive country coverage at a high level of disaggregation for many years. The data span from 1995 to 2012 and include around 5,000 Harmonized System (HS) six-digit codes for more than 160 countries.

To proxy export prices at the product level, we compute unit values using harmonized trade quantities and values in current US dollars. These unit values are then converted into importer's currency using the bilateral exchange rate data from the IMF's International Financial Statistics. Note that the export prices are free on board (FOB) and can be interpreted as wholesale prices rather than retail prices, i.e., they are not directly affected by transportation costs or tariffs. However, it is important to note that unit values may depart from real export prices. In particular, price proxies based on unit values suffer from measurement errors due to product heterogeneity and unobserved quality differences within each HS six-digit code. To address this issue, we first use product fixed effects that partly control for unobserved, systematic errors. Second, we also exclude annual changes in unit values that are larger than $200 \%$. We consider these large unit value changes as unrealistic measures of price changes. This definition of outliers removes roughly $1 \%$ of the total number of observations. However, we want to stress that our results below are robust to alternative definitions of outliers, i.e., removing the top $1 \%$ of price changes in each product category or removing no outliers at all.

Importantly also, all our equations are weighted by the magnitude of the flows: large trading partners and large sectors are given a higher weight. This allows discounting smaller trade flows, which are generally measured less precisely.

\footnotetext{
${ }^{7}$ Mumtaz et al. (2006) find evidence that neglecting cross-sector heterogeneity biases pass-through estimates.
} 


\subsection{Exchange rate pass-through}

\subsubsection{Baseline regression}

We start by describing the export side and then proceed with the import side. Consider exporting country $[i]$. According to equation 3 , the exchange rate pass-through coefficient $\beta_{[i]}^{X}$ can be estimated using the following estimation equation:

$$
d \log \left(p_{[i] j k t}\right)=\alpha_{[i]}-\beta_{[i]}^{X} d \log \left(s_{i j t}\right)+f_{[i] j k}+e_{i j k t},
$$

where $d \log \left(p_{[i] j k t}\right)$ is the change of the $\log$ of export unit values (prices) of exporting country $i$ to importing country $j$ of product $k$ at time $t$ expressed in the importer's currency and $k$ refers to a six-digit HS $\operatorname{code} \cdot \log \left(s_{[i] j t}\right)$ is the log of the bilateral nominal exchange rate in terms of the exporting country $i$ with respect to the importing country $j$ at time $t .{ }^{8} \quad \beta_{[i]}^{X}$ measures how exporters change their price according to a change in the exporter's exchange rate and is the coefficient of interest. If $\beta_{[i]}^{X}=1$, then exporters do not change their export price in terms of exporter's currency and pass the change in the exchange rate completely on to importers, i.e., complete pass-through.

Equation 4 also includes bilateral product fixed effects, $f_{[i] j k}$. They control for the unit of account of the unit values. Unit values are defined as the value of the good divided by the quantity shipped and thus depend on the unit measurement of the underlying trade quantity, i.e., the unit value per kilogram or the unit value per piece shipped. Product-time fixed effects ensure that we focus only on time changes within a product group and not across products (i.e., we do not compare apples and oranges). More importantly, these fixed effects also capture price discrimination of exporters across different importing countries that are constant over time, i.e., trends in relative price changes specific to the pair of countries and the product.

Similar to the export prices, we can estimate exchange rate pass-through into import prices. The countryspecific import price regression is given by the log linear change of equation 2 :

$$
d \log \left(p_{i[j] k t}\right)=\alpha_{[j]}-\beta_{[j]}^{M} d \log \left(s_{i j t}\right)+f_{i[j] k}+e_{i j k t},
$$

where $d \log \left(p_{i[j] k t}\right)$ is the change of the log of import prices in importing country $[j]$ from exporting country $i$ of product $k$ at time $t$ denoted in importer's currency. The difference with respect to equation 4 is that we estimate the country-specific exchange rate elasticity of import prices, $\beta_{[j]}^{M}$, by using the variation across exporters $i$. Equation 4 uses the variation across importers $j$. Concerning the interpretation of the elasticity, if $\beta_{[j]}^{M}=0$ the importer's price does not change when the exporter's currency changes. This implies that exporters, who price their goods in the importing country's currency, absorb all changes in the exchange rate, i.e., complete pricing to market and no pass-through. On the other hand, if exporters change their price one-to-one as a result of a change in the importer's currency, we have complete pass-through and the elasticity should be $\beta_{[j]}^{M}=1$.

Note that there is a relationship between the export and the import exchange rate pass-through. Under the assumption that $\beta_{[i]}^{X}$ in equation 4 and $\beta_{[j]}^{M}$ in equation 5 are unbiased and consistently estimated, then the weighted average cross-country exchange rate pass-through for exports should be equal to the weighted average of the exchange rate pass-through for imports. ${ }^{9}$ At the same time, there is not necessarily a correlation between the import and export exchange rate elasticity at the individual country level. For example, a country may be characterized by complete pass-through on the export side and zero pass-through on the import side.

All our equations are estimated using weighted ordinary least squares (OLS). We use the value of each bilateral flow to calculate the two-period weights as in the computation of Törnqvist price indices. ${ }^{10}$ Table 4 presents the 51

\footnotetext{
${ }^{8}$ We use the same definition as before.

${ }^{9}$ See Appendix.

${ }^{10}$ We follow Gaulier et al. (2008) and define the weighting variable as follows:
} 
country-specific results for the equations 4 and 5. However, note that these coefficients are likely to be biased due to the correlation of the exchange rate with marginal costs and markups. Next, we include a series of fixed effects and explain how they correct for the biases step by step.

\subsubsection{Fixed-effect regressions}

In the augmented specification, we include the following time-varying exporter and product fixed effects, $f_{[i] k t}$, in the export price equation 4 :

$$
d \log \left(p_{[i] j k t}\right)=\alpha_{[i]}+\beta_{[i]}^{X} d \log \left(s_{i j t}\right)+f_{[i] k t}+f_{[i] j k}+e_{i j k t}
$$

The $f_{[i] k t}$ fixed effects contain product-time fixed effects, $f_{k t}$, i.e., product changes over time that are common to all exporters and importers. These fixed effects control, among others, for product-specific demand changes over time that are common to all countries (e.g., world demand for cars increases the price of cars relative to bicycles). More importantly, the product-time fixed effects also include an exporting country dimension, which addresses the bias caused by unobserved marginal costs, $m c_{i k t}$. As discussed in the previous section, for example due to intermediate imports, parts of the marginal costs vary with the exchange rate and induce an upward bias in the $\beta_{[i]}^{X}$ coefficient. In addition, these fixed effects also capture changes in product-specific properties that are common to all importing countries, for example, quality upgrading.

The inclusion of these fixed effects implies that $\beta_{[i]}^{X}$ is identified by heterogeneous exchange rate changes across importing countries. Therefore, the coefficient $\beta_{[i]}^{X}$ can be seen as the pricing-to-market coefficient à la Krugman (1986). To give a concrete example, consider French exporters that sell to Japan and the United States and suppose the euro depreciates 10\% against the US dollar and 5\% against the Japanese yen. By the arbitrage condition in the foreign exchange rate market, the Japanese yen appreciates $5 \%$ against the US dollar. Note that the price adjustment of French exporters due to the common depreciation of the euro against both countries is absorbed by the time-varying exporter-product fixed effect. The remaining identifying variation is the change in the price of French exporters charged in the US market compared with the one charged in the Japanese market due to the 5\% appreciation of the yen against the US dollar.

Regarding the import price equation 5, the key difference with respect to the export equation 6 lies in the included fixed effects:

$$
d \log \left(p_{i[j] k t}\right)=\alpha_{[j]}+\beta_{[j]}^{M} d \log \left(s_{i j t}\right)+f_{[j] k t}+f_{i[j] k}+e_{j k t}
$$

Instead of exporter-product-time fixed effects, the import price regressions contain importer-product-time fixed effects, $f_{[j] k t}$. These fixed effects control for global product-specific demand shocks, for the unit of account of unit values as well as any importer time variation that is common to all products, for example, higher inflation or product-specific technology progress or demand that changes the price level in a particular product category. Based on the discussion in Section 2, the importer-product-time controls also for local price changes that are correlated with the exchange rate as well as changes in distribution costs that are common to all exporters.

$$
w_{i j k t}=\frac{1}{2}\left[\frac{V_{i j k t-1}}{V_{i t-1}}+\frac{V_{i j k t}}{V_{i}}\right],
$$

where $i, j, k$, and $t$ refer to the exporting country, the importing country, the product and time. $V_{i j k t}$ is the value of the bilateral trade flow denominated in exporter's currency in the exporting equations and in importer's currency in the importing country. $V_{i t}=\sum_{j k} V_{i j k t}$ is total exports of country $i$ at time $t$. 


\subsubsection{Two-step procedure}

One key issue is that we cannot include time-varying exporter and importer-product fixed effects because these fixed effects would absorb all exchange rate changes. Note that for any triplet of countries $a, b$ and $c$, we have $\log s_{a b}=-\log s_{b a}$ and $\log s_{a b}=\log s_{a c}-\log s_{c b}$ by arbitrage. The within transformation with time-varying exporter and importer-product fixed effects implies that $\log s_{a b}-\log s_{a c}-\log s_{c b}$ equals zero. In this sense, the exchange rate is a monadic variable, see Head and Mayer (2014). To circumvent this problem, we take advantage of our bilateral data set and follow the suggested two-step approach of Baker and Fortin (2001) and Redding and Venables (2004) based on Pagan (1984). First, we proxy unobserved marginal costs with a generated regressor from a fixedeffect regression, a method pioneered by Schmalensee and Joskow (1986). In the second step, we use the generated regressor obtained from the first step as explanatory variable in the estimation of the exchange rate pass-through. To be more explicit, consider again the export price equation 1 and observe that marginal costs are independent from the destination country $j$. If we estimate the following export price equation for country $i$,

$$
d \log \left(p_{[i] j k t}\right)=\alpha_{[i]}+\beta_{[i]}^{X} d \log s_{i j t}+f_{[i] k t}+f_{[i] j k}+e_{i j k t},
$$

then the exporter fixed effect $f_{[i] k t}$ will capture all effects that are specific to the exporter (including unobserved marginal costs) and are independent of the exchange rate. Given our export pricing model, we can proxy marginal costs via a linear function of the estimated fixed effect and an error component $\left(u_{[i] k t}\right)$, i.e., $\widehat{m c_{[i] k t}}=a \hat{f}_{[i] k t}+u_{[i] k t}$.

In the second step, we use this estimated fixed effect as a generated regressor in the import price equation:

$$
d \log \left(p_{i[j] k t}\right)=\alpha_{[j]}+\beta_{[j]}^{M} s_{i[j] t}+\gamma_{[j]} \widehat{m c_{i k t}}+f_{[j] k t}+f_{i[j] k}+e_{i[j] k t}
$$

where import price pass-through coefficient $\beta_{[j]}^{M}$ is now consistently estimated, if (1) the exchange rate is uncorrelated to the approximation error, i.e., $\operatorname{Corr}\left(s_{i[j] t}, u_{[i] k t}\right)=0$, and (2) the errors are uncorrelated $\operatorname{Corr}\left(u_{[i] k t}, e_{i[j] k t}\right)=$ 0 . Given that $\widehat{m c_{i k} t}$ is estimated net of the exchange rate, we assume that this assumptions holds. Another important requirement is that the pass-through into import prices is different from the pass-through into export prices, i.e., $\beta_{[j]}^{M} \neq \beta_{[i]}^{X}$. Otherwise the estimated coefficient $\beta_{[i]}^{X}$ would be zero in equation 8 .

We can follow a similar approach when estimating the export pass-through coefficient. We reverse the order and run the import price equation in the first stage. In this case, the importer-time fixed effects will capture all unobserved changes that are common to all exporters. Given the import price equation 3, the importer fixed effect

will proxy for changes in strategic price setting, $\widehat{\theta_{[j] k t}}=\hat{f}_{[j] k t}+v_{j k t}$. The corresponding second stage export price equation is

$$
d \log \left(p_{[i] j k t}\right)=\alpha_{[i]}+\beta_{[i]}^{X} d \log \left(s_{i j t}\right)+\gamma_{[i]} \widehat{\theta_{j k t}}+f_{[i] j k}+f_{[i] k t}+e_{i j k t} .
$$

We obtain a consistent estimate for the export price pass-through, $\beta_{[i]}^{X}$, if $\operatorname{Corr}\left(s_{i j t}, v_{[j] k t}\right)=0$ and $\operatorname{Corr}\left(v_{[j] k t}, e_{i j k t}\right)=$ 0.

\subsection{Quantity elasticities}

Before turning to the results of the exchange rate pass-through on prices, we will next discuss the elasticity of trade quantities. The combination of the exchange rate price and quantity elasticities allows computing the reaction of the trade balance and assessing whether an exchange rate depreciation will cause a balance of trade improvement. To estimate the elasticity of trade quantities with respect to the exchange rate, we use the following regression specifications for exports:

$$
d \log \left(q_{[i] j k t}\right)=\alpha_{[i]}+\delta_{[i]}^{X} d \log \left(s_{i j t}\right)+\vartheta_{[i]} d \log \left(y_{j t}\right)+f_{[i] j k}+e_{i j k t}
$$


and for imports:

$$
d \log \left(q_{i[j] k t}\right)=\alpha_{[j]}+\delta_{[j]}^{M} d \log \left(s_{i j t}\right)+\vartheta_{[j]} d \log \left(y_{j t}\right)+f_{i[j] k}+e_{i j k t}
$$

Equations 10 and 11 are the baseline quantity equations. The dependent variable is the quantity of product $k$ exported from country $i$ to country $j$ at time $t$. The log change of the importer's GDP, $d \log \left(y_{j t}\right)$, controls for local demand conditions. ${ }^{11}$ Estimating the quantity regressions in log changes is particularly important because we control for the unit of account of the underlying quantity traded, i.e., kilogram, tons or pieces, as well as quality differences across countries that are constant over time. In addition, the time-varying product fixed effects, $f_{i j k}$, account for product-specific trends.

Regarding our predictions on the exchange rate elasticities, the impact of a depreciation on export quantities $\left(\delta^{X}\right)$ is expected to be positive, while negative for the quantities imported $\left(\delta^{M}\right)$.

\subsection{Trade balance (Marshall-Lerner conditions)}

In order to assess whether an exchange rate depreciation improves the trade balance, we need price elasticities of exports and imports. To see how exchange rate changes influence the trade balance, we derive the Marshall-Lerner condition. Let's define the trade balance $T B_{i}$ :

$$
T B_{i}=s_{i} P_{i}^{X} X_{i}-P_{i}^{M} M_{i}
$$

as the difference between the export sales (export price $P_{i}^{X}$, denoted in foreign currency, times volume $X_{i}$ ) multiplied by the nominal effective exchange rate $s_{i}$ and the import expenditure (import price $P_{i}^{M}$, denoted in domestic currency, times volume $M_{i}$ ). Next, take the derivative of the trade balance with respect to the nominal effective exchange rate $s_{i}:{ }^{12}$

$$
\frac{\partial T B_{i}}{\partial s_{i}}=P_{i}^{X} X_{i}+\frac{\partial P_{i}^{X}}{\partial s_{i}} s_{i} X_{i}+\frac{\partial X_{i}}{\partial P_{i}^{X}} \frac{\partial P_{i}^{X}}{\partial s_{i}} s_{i} P_{i}^{X}-\left(\frac{\partial P_{i}^{M}}{\partial s_{i}} M_{i}+\frac{\partial M_{i}}{\partial P_{i}^{M}} \frac{\partial P_{i}^{M}}{\partial s_{i}} P_{i}^{M}\right) .
$$

Using the definition of the exchange rate pass-through

$$
\frac{\partial P_{i}^{X}}{\partial s_{i}} \frac{s_{i}}{P_{i}^{X}}=-\beta_{i}^{X} \text { and } \frac{\partial P_{i}^{M}}{\partial s_{i}} \frac{s_{i}}{P_{i}^{M}}=\beta_{i}^{M}
$$

and the price elasticities of trade volumes

$$
-\frac{\partial X_{i}}{\partial P_{i}^{X}} \frac{P_{i}^{X}}{X_{i}}=\mu_{i}^{X} \text { and }-\frac{\partial M_{i}}{\partial P_{i}^{M}} \frac{P_{i}^{M}}{M_{i}}=\mu_{i}^{M}
$$

we can rewrite the previous equation as

$$
\frac{\partial T B_{i}}{\partial s_{i}} \frac{s_{i}}{T B_{i}}=\frac{s_{i} P_{i}^{X} X_{i}}{T B_{i}}\left(1-\beta_{i}^{X}+\mu_{i}^{X} \beta_{i}^{X}\right)-\frac{P_{i}^{M} M_{i}}{T B_{i}}\left(\beta_{i}^{M}-\mu_{i}^{M} \beta_{i}^{M}\right) .
$$

Under the assumption that trade is balanced, the Marshall-Lerner condition under which the trade balance improves after an exchange rate depreciation becomes

\footnotetext{
${ }^{11}$ The quantity equations are, for example, consistent with a two-tier CES demand system, where changes in GDP capture aggregate demand changes, see amongst others Imbs and Méjean (2015), and more generally with aggregate exchange rate regressions in the pricing-to-market literature, see Burstein and Gopinath (2014).

${ }^{12}$ In line with the definition of the bilateral exchange rate, a depreciation of the nominal exchange rate of exporter $i$ increases $s_{i}$.
} 


$$
\beta_{i}^{X}\left(1-\mu_{i}^{X}\right)+\beta_{i}^{M}\left(1-\mu_{i}^{M}\right)<1 .
$$

In order to verify the Marshall-Lerner conditions, we need to calculate the price elasticities of exports $\left(\mu^{X}\right)$ and imports $\left(\mu^{M}\right)$. These elasticities can be estimated using the exchange rate as an exogenous shock to prices. Consider the case for exports:

$$
\frac{\partial \log X_{i}}{\partial \log s_{i}}=\frac{\partial \log X_{i}}{\partial \log P_{i}^{X}} \frac{\partial \log P_{i}^{X}}{\partial \log s_{i}}=\frac{\partial \log X_{i}}{\partial \log P_{i}^{X}}\left(-\beta_{i}^{X}\right)
$$

or, simplifying,

$$
\mu_{i}^{X}=\frac{\delta_{i}^{X}}{\beta_{i}^{X}}
$$

and, equivalently for imports, we have

$$
\frac{\partial \log M_{i}}{\partial \log s_{i}}=\frac{\partial \log M_{i}}{\partial \log P_{i}^{M}} \frac{\partial \log P_{i}^{M}}{\partial \log s_{i}}=\frac{\partial \log M_{i}}{\partial \log P_{i}^{M}}\left(\beta_{i}^{M}\right)
$$

which simplifies to

$$
\mu_{i}^{M}=-\frac{\delta_{i}^{M}}{\beta_{i}^{M}}
$$

Next, we discuss the main results of the estimation of the exchange rate elasticities for import and export prices as well as for the corresponding quantity elasticities.

\section{Results}

\subsection{Exchange rate pass-through}

Figure 1 and Figure 2 plot the baseline results without fixed effects. The corresponding table with the detailed results is at the end of the paper (see Table 4 and Table 5). Overall, the estimation results show that the coefficients of the key variables are statistically significant, with expected signs and magnitudes for all of the 51 countries.

Starting with export prices, the average elasticity of export prices denominated in the importer's currency with respect to the exchange rate, i.e., the exchange rate pass-through, is 0.65 . However, as Figure 1 shows, there is a lot of heterogeneity across countries. We observe an elasticity of 1 for Switzerland, Norway, Guatemala, Philippines, Chile, Singapore and India, i.e., the exporters from these countries do not change their export prices when the exchange rate varies, implying full pass-through for their trading partners. The following countries, however, adopt a complete pricing-to-market strategy and change their price one-to-one with the exchange rate: Argentina, Costa Rica, Indonesia and Ireland. In these countries, exporters do not change their export price in terms of the importer's currency with the exchange rate since their export elasticity is not significantly different from zero. In general, the average exchange rate elasticity of export prices is higher for advanced economies (on average, 0.72) than for emerging-market economies (on average, 0.59). A possible explanation may be that exporters from emerging-market economies have more market power than those from advanced economies. Turning to imports, the average exchange rate elasticity is 0.48 . Only Costa Rica has a pass-through coefficient that is not significantly different from 1, i.e., we observe incomplete pass-through in most countries. In contrast, countries with a relatively low exchange rate elasticity are Guatemala, Singapore, Sri Lanka and Saudi Arabia. However, there is no significant 


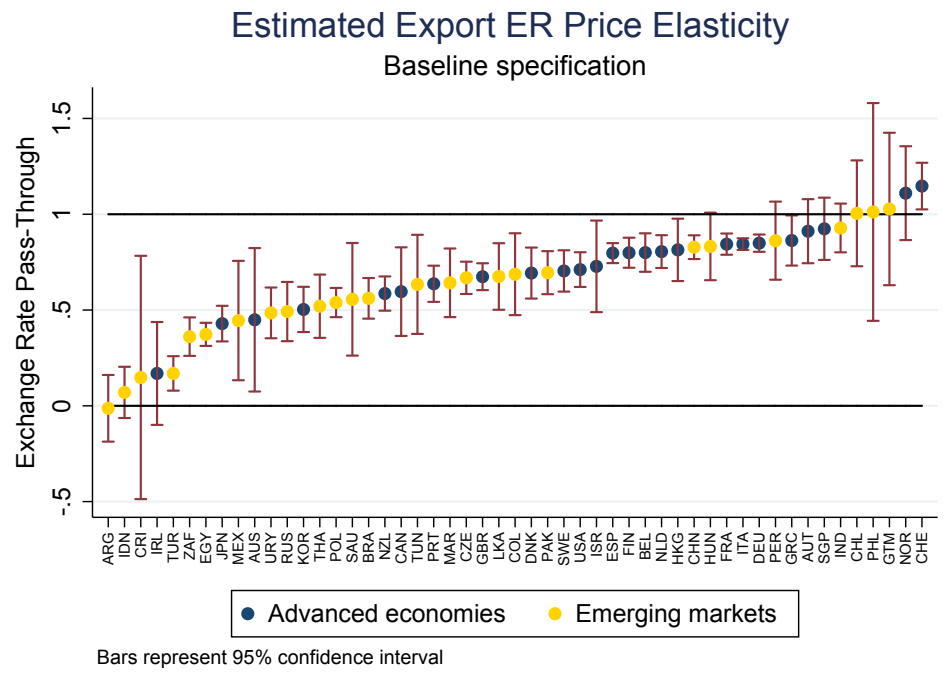

Figure 1: Estimated Exchange Rate Elasticity of Export Prices

Note: This chart reports point estimates of the exchange rate elasticities as shown in Table 4. Trade prices are expressed in the importer's currency so the coefficients can be read directly as "pass-through coefficients" for the importing countries. The blue circles indicate coefficient estimates for advanced economies and the yellow circles for emerging-market economies. The vertical lines denote $95 \%$ confidence intervals.

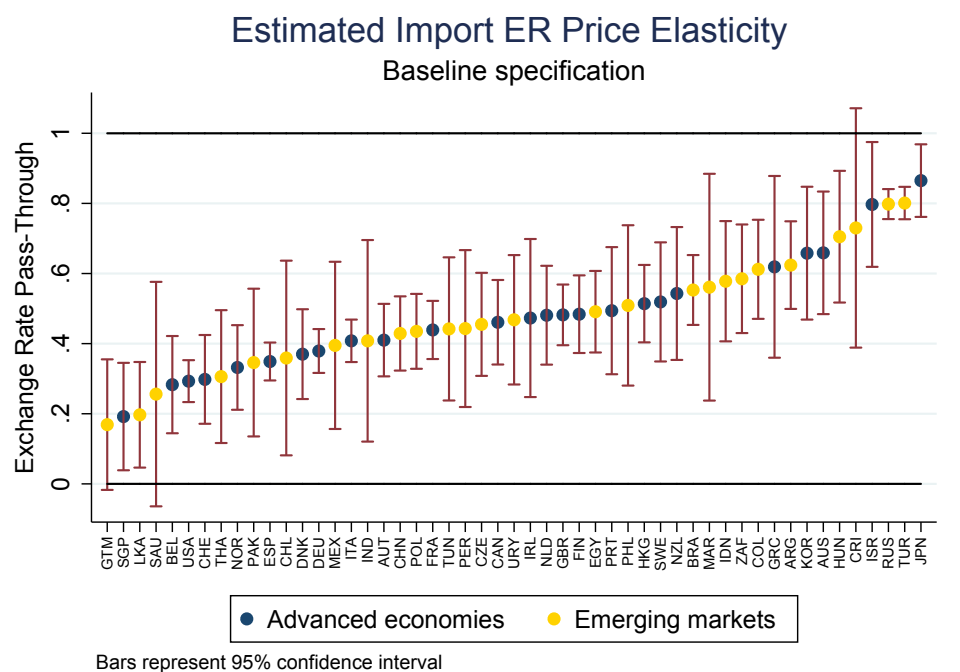

Figure 2: Estimated Exchange Rate Elasticity of Import Prices

Note: This chart reports point estimates of the exchange rate elasticities as shown in Table 4 . The blue circles indicate coefficient estimates for advanced economies and the yellow circles for emerging-market economies. The vertical lines denote $95 \%$ confidence intervals. 
difference in the import pass-through between emerging markets (on average, 0.49) and advanced economies (on average, 0.47$)$.

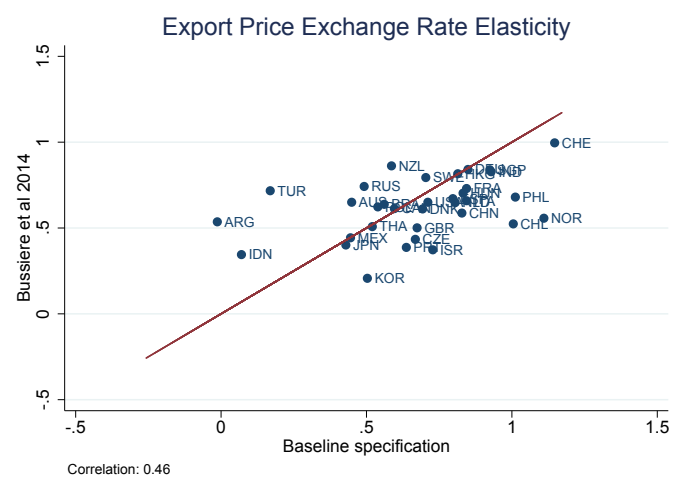

(a) Exports

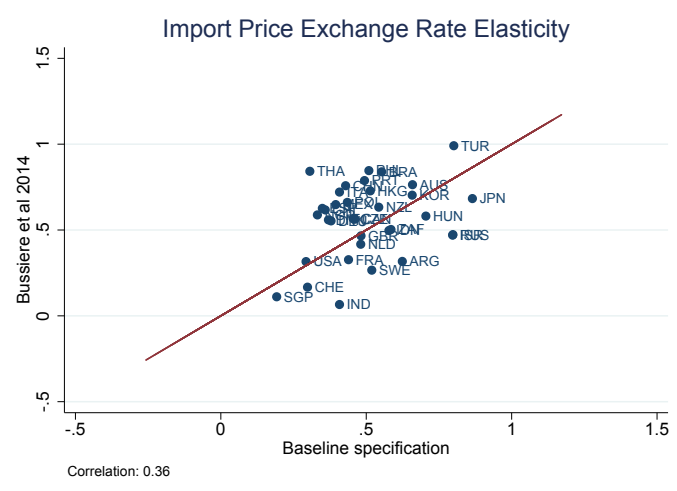

(b) Imports

Figure 3: Export and Import Exchange Rate Pass-Through: comparison of estimates of the baseline specification with Bussière et al. (2014).

Note: The red line corresponds to the 45 degree line.

Our results, based on a unified data set, are broadly consistent with existing country-specific studies for advanced economies, compiled from different data sources. For the United States, our import pass-through coefficient is estimated to be around $29 \%$. This result is in line with Ihrig et al. (2006), who find an estimate of $32 \%$, and Corsetti et al. (2007) at 27\%, as well as Gopinath (2015), who finds 35\%. Gopinath (2015) also provides recent estimates for Turkey and Japan using aggregate import price data. Our product-level-based estimates show 80\% pass-through for Turkey and $87 \%$ for Japan, which are slightly lower than the 82 and $92 \%$ respectively found by Gopinath (2015). For the United Kingdom, we find an exchange rate effect of $48 \%$, in line with that of Campa and Goldberg (2005), equal to 46\%, and Bussière (2013), at 48\%. More generally, we can compare our elasticities based on product-level data with the macro exchange rate pass-through elasticities from Bussière et al. (2014), who investigate a similar sample in terms of country observations, see Figure 3. For exports the correlation is 0.46 and for imports 0.36. In line with Bussière et al. (2014), we also find a strong relationship between the estimated elasticities for export and import prices across countries. The correlation coefficient is 0.52 .

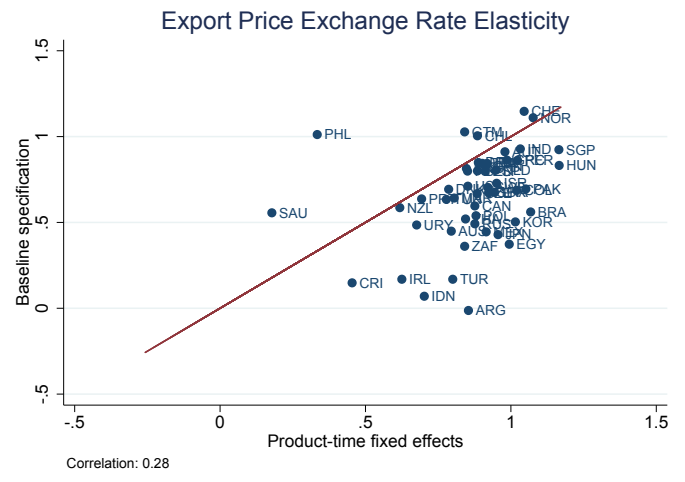

(a) Exports

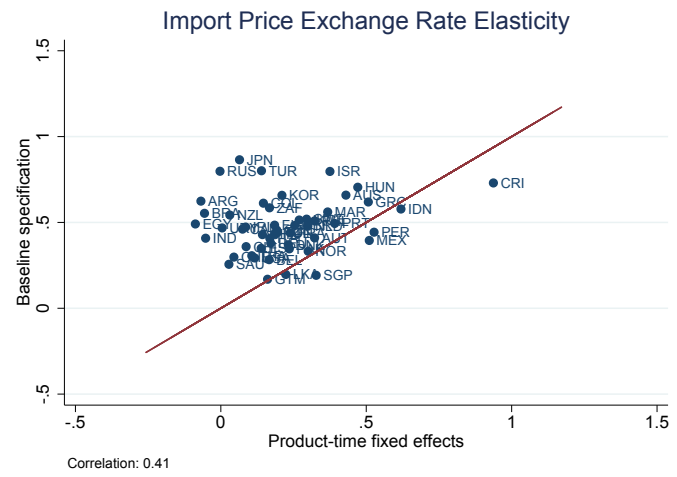

(b) Imports

Figure 4: Export and Import Exchange Rate Pass-Through: comparison of estimates of the baseline specification with the fixed-effect specification.

Note: The red line corresponds to the 45 degree line. 
In the next step, we can compare the results with no time fixed effects to the 1-step regression with timevarying country and product fixed effects and analyse the severity of the marginal cost bias for exports and price complementarity bias for imports. Figure 4 shows the comparison for export (Figure $4(\mathrm{a})$ ) and for import prices (Figure 4(b)) by plotting the 1-step estimates on the horizontal axis and the baseline estimates on the vertical axis. In the case of export prices, we observe that, with the exceptions of the Philippines and Saudi Arabia and to a lesser extend Chile and Guatemala, the 1-step estimates are higher than the baseline ones. Net of changes in the marginal costs, the average exchange rate pass-through increases substantially from 0.65 to 0.87 . Note that this implied bias is consistent with our pricing model, which suggests a positive correlation between marginal costs and exchange rate changes, see Section 2.1.2. Similarly, in the case of imports, we observe that with the correction of (importer-)time fixed effects, the estimates are lower than the baseline ones with the exception of Costa Rica, Singapore, Mexico, Peru and Indonesia. Neglecting price adjustments caused by complementarities in price-setting in the importing destination reduces the average exchange rate pass-through into import prices substantially from 0.49 to 0.22 . The direction of the bias is consistent with the pricing model in Section 2.1.1. Price adjustments are positively correlated with the exchange rate and cause a downward bias in the exchange rate pass-through to import prices if omitted from the regression. ${ }^{13}$

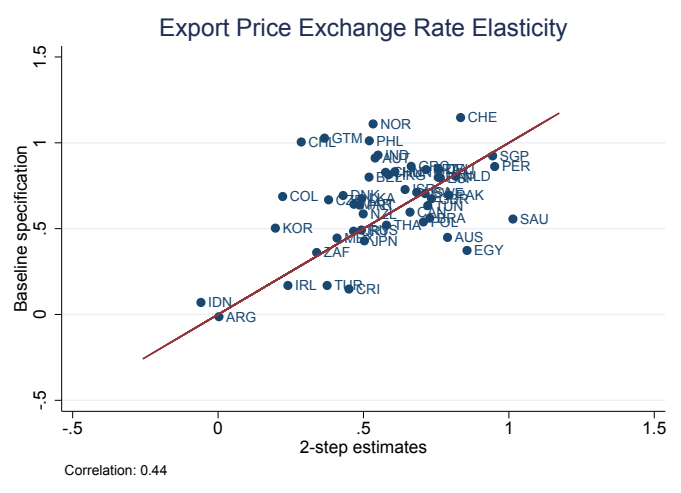

(a) Exports

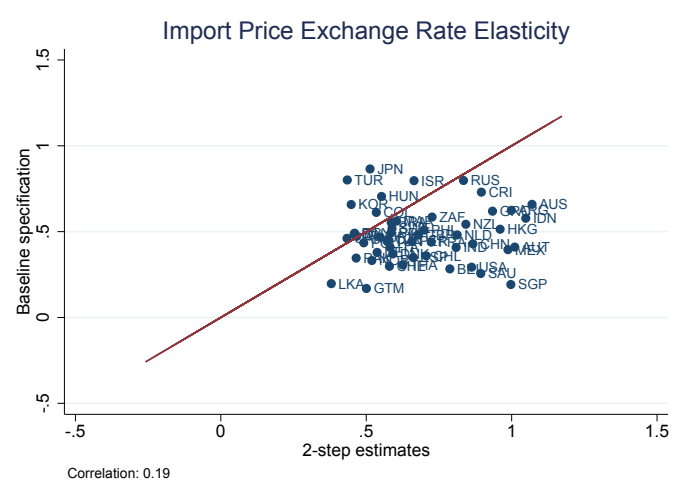

(b) Imports

Figure 5: Export and Import Exchange Rate Pass-Through: comparison of baseline estimates with the 2-step approach Note: The red line corresponds to the 45 degree line.

Finally, we can compare the 2-step results with the baseline specification of no time fixed effect. Doing so simultaneously controls for marginal costs and local price changes that are correlated with the exchange rate. Figure 5 shows the comparison for export (Figure 5(a)) and for import prices (Figure 5(b)) by plotting the 2-step estimates on the horizontal axis and the baseline estimates on the vertical axis. In the case of exports, based on the 2-step approach, the reaction of export prices in importer currency to exchange rate changes is the lowest with 0.57, compared with 0.65 with no time fixed effects and to 0.87 with only product-time fixed effects. Note that these changes are again consistent with the correlation implied by the pricing equation in Section 2 . In the case of export prices, controlling for marginal costs increases the elasticity, while controlling for local prices reduces the elasticity. As for imports, if we proxy for marginal costs and local prices the average pass-through is the highest with 0.68 compared to 0.49 in the case of no fixed effects and to 0.22 with product fixed effects only. Again, the direction of the bias is consistent with the pricing model.

\footnotetext{
${ }^{13}$ It is a bias given the framework outlined in Section 2 . The baseline regressions are nevertheless very informative as they report the reaction of prices and quantities to exchange rate changes as observed in the aggregate data. On the other hand, the fixed-effect regressions shed light on the role of specific factors that determine the aggregate response of trade prices and quantities to changes of the exchange rate.
} 


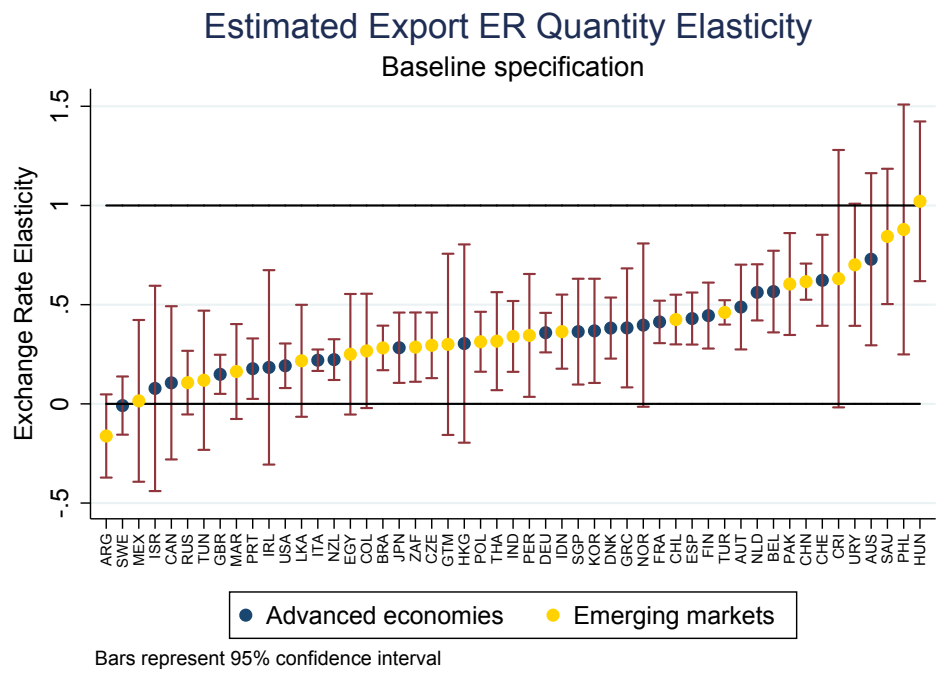

Figure 6: Estimated Quantity Elasticity for Exports

Note: This chart reports point estimates of the exchange rate elasticities as shown in Table 5. The blue circles indicate coefficient estimates for advanced economies and the yellow circles for emerging-market economies. The vertical lines denote $95 \%$ confidence intervals.

\subsection{Quantity elasticities}

This subsection presents the estimated baseline quantity elasticities. Looking at the export side, Figure 6 plots the quantity elasticities reported in Table 5 . Note that all countries have either a zero or a positive quantity elasticity of exports, i.e., an exchange rate depreciation raises the export quantity. While the average elasticity across all countries is 0.35 , advanced economies tend to have a slightly higher average elasticity with 0.37 compared to an average elasticity of 0.32 for emerging-market economies. However, this difference is not statistically significant. Countries with a high elasticity are the Philippines and Hungary with 0.88 and 1 . On the other hand, countries with low export quantity elasticities that are not significantly different from zero are Argentina, Sweden and Mexico. In general, countries whose export quantities react more strongly to exchange rate changes tend to be countries characterized by a high exchange rate elasticity of export prices (in the importing country's currency, i.e., high pass-through). The cross-country correlation between the two types of elasticities is 0.4.

Turning to import quantity elasticities, our results in Table 5 and plotted in Figure 7 show that all countries have either a zero or a negative quantity elasticity, i.e., an exchange rate depreciation reduces the quantity of goods imported. The average cross-country elasticity is -0.2 and insignificant between the two country groups. The average elasticity of emerging markets is -0.22 and -0.19 for advanced economies. Countries with strong reactions of import quantities are Costa Rica, Peru, Colombia, Morocco and Israel with elasticities smaller than -0.5. At the same time, for many countries we do not find a response that is significantly different from zero, suggesting that import demand in most countries depends more on income and the business cycle rather than to the exchange rate, see Hooper et al. (2002). Similar to the export quantity elasticities, countries with a stronger reaction in import prices tend to have stronger reactions in their import volumes. The correlation between the import price and quantity elasticities is 0.36 .

Table 5 also shows that the estimated coefficient of GDP in both export and import quantity equations is close to or slightly above 1 . In theory, there is no reason why this coefficient should be different from one, but this is a common result in the empirical literature. One potential explanation is that GDP is a crude measure of demand that does not take into account the different import contents of GDP components (see Bussière et al. (2013) for instance). 


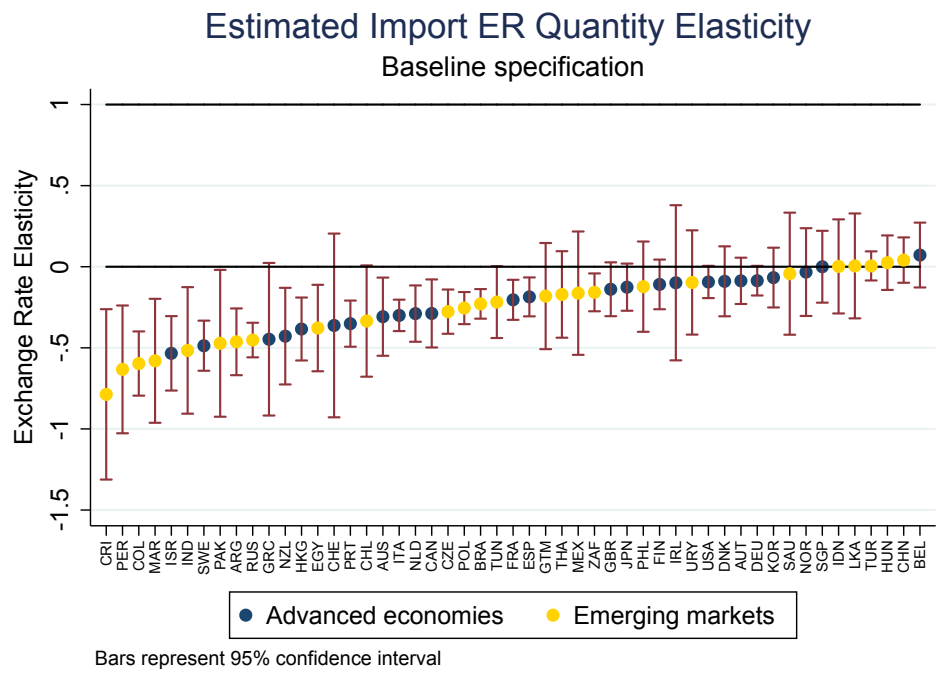

Figure 7: Estimated Quantity Elasticity for Imports

Note: This chart reports point estimates of the exchange rate elasticities as shown in Table 5. The blue circles indicate coefficient estimates for advanced economies and the yellow circles for emerging-market economies. The vertical lines denote $95 \%$ confidence intervals.

As in the price equations, we introduce country and product time-varying fixed effects in the quantity equations. The coefficients are affected but to a lesser extent than in the price equations. On average, we find that the median elasticity of export quantity increases from 0.35 to 0.47 . One possible explanation is that the time-varying fixed effects capture supply factors not taken into account in the baseline specification, such as productivity shocks, which are associated with an appreciation of the exchange rate and a simultaneous increase in export quantities. Taking the factors into account increases the elasticity. We note that the increase in quantity elasticities is in line with the higher elasticity of export prices when changing from the baseline to the fixed-effect regression. By contrast, switching to the fixed-effect specification leaves the elasticity broadly unchanged for import volumes (a slight increase from -0.25 to -0.22 ).

\subsection{The reaction of the trade balance}

Based on these results, we can now verify the Marshall-Lerner conditions by plugging in the estimated price and quantity elasticities given in Table 4 and Table 5 into equation 12. Our estimates imply that the Marshall-Lerner conditions are verified for all countries. In addition, we can calculate the implied effect of a nominal exchange rate depreciation on net exports (which equals a change in output assuming no changes in consumption, investment and government spending) as

$$
\frac{\partial T B_{i}}{\partial s_{i}} \frac{s_{i}}{Y_{i}}=\frac{s_{i} P_{i}^{X} X_{i}}{Y_{i}}\left(1-\beta_{i}^{X}+\mu_{i}^{X} \beta_{i}^{X}\right)-\frac{P_{i}^{M} M_{i}}{Y_{i}}\left(\beta_{i}^{M}-\mu_{i}^{M} \beta_{i}^{M}\right) .
$$

To calculate the implied effect, we use data on the shares of exports and imports with respect to GDP $\left(s_{i} P_{i}^{X} X_{i} / Y_{i}\right.$ and $\left.P_{i}^{M} M_{i} / Y_{i}\right)$ as of 2012. Combining the estimates in Table 4 and Table 5 together with the trade shares, we find that on average a $10 \%$ depreciation in the exchange rate increases net exports by $2 \%$ of GDP compared with 1.7 according to Leigh et al. (2015). Table 10 and Figure 8 show the precise estimates for all countries in our sample. Countries with the strongest effects are Hong Kong and Ireland. For those countries, a 10\% depreciation translates into an increase of 7 to 8 percentage points in net exports over GDP. Countries where the exchange rate has only marginal effects on the domestic economy are Japan, United States, Norway and Great Britain. For these countries, 


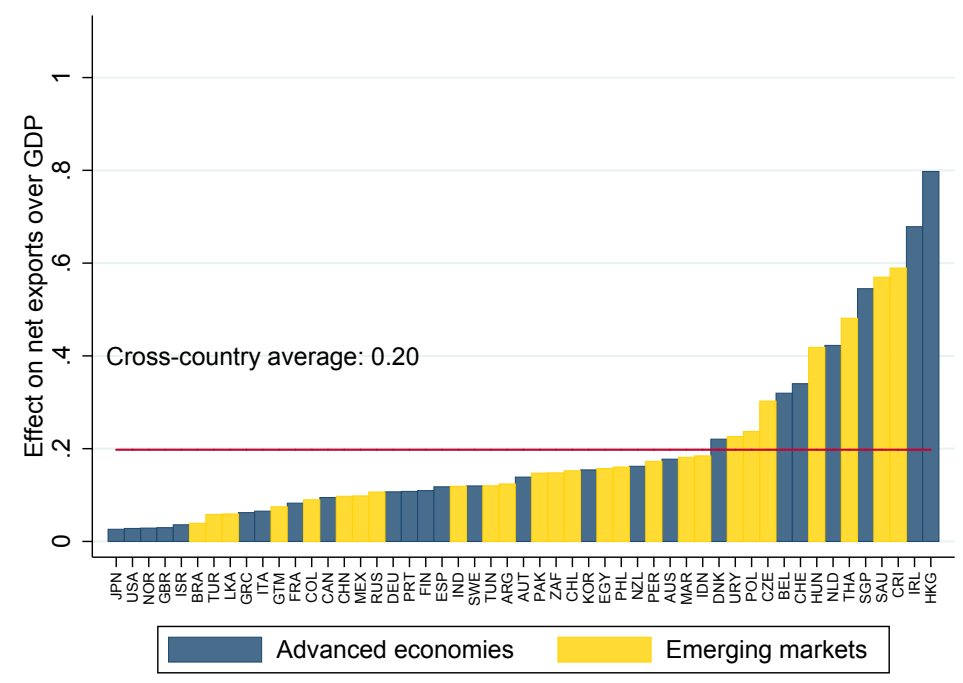

Figure 8: Effect on net exports over GDP based on estimated exchange rate elasticities and data on exports, imports and GDP in 2012

a $10 \%$ depreciation improves net exports by less than $0.3 \%$. Cross-country differences reflect to a large extent their openness to trade (the correlation between the trade balance effect and the openness index is 0.76).

Instead of using the baseline estimates, we also calculate the response of the trade balance to exchange rate changes using the coefficients of the 2-step fixed-effect approach reported in Table 8 and Table 9 . The average implied response of the trade balance to a $10 \%$ exchange rate depreciation is $2.8 \%$ of GDP, notably higher than in the baseline. However, the cross-country ranking in terms of magnitude of the effect remains broadly unchanged. The correlation between the two estimates is 0.75 . Overall, the estimated response of the trade balance is similar to Gust et al. (2009), who also investigate the role of incomplete exchange rate pass-through for the adjustment of global imbalances in the wake of exchange rate changes.

\section{Additional robustness tests and further results}

The aim of this section is to provide a set of additional tests of robustness and further interpretation of some results. As a first robustness test, we added control variables in the baseline regression; specifically, we added inflation of the exporting country to capture aggregate changes in the production cost and inflation of the importing country to account for changes in the price of local goods. The results for prices are presented in Table 11 and Table 12, while Table 13 and Table 14 report the estimates for trade volumes. Including inflation leaves the results broadly unchanged. For export prices and quantities, the mean elasticity changes from 0.65 to 0.64 and from 0.35 to 0.47 , respectively, but these differences are not significant. Similarly, when we compare the mean elasticity for import prices (0.51 versus 0.48$)$ and quantities ( 0.30 versus 0.28$)$, their changes are not statistically significant either. The correlation with our baseline coefficients is very high, i.e., above 0.75 , with the exception of the import quantities coefficients where the correlation is 0.64 . Overall, our baseline approach captures well aggregate changes in competitiveness caused by inflation.

As extensions to our baseline results, we also consider an augmented version of the model, where we include two lags of the exchange rate to analyse the time effects of the exchange rate adjustments. The results are in Tables 15 to 18 . Note that for the majority of countries all the exchange rate effects materialize within one year (most of the lagged variables are not significant).

Next, we estimate country-specific price and quantity exchange rate elasticities for different product classes, 


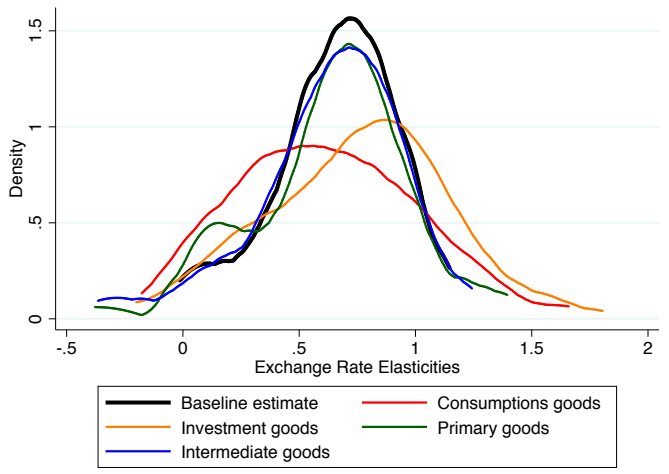

(a) Export prices

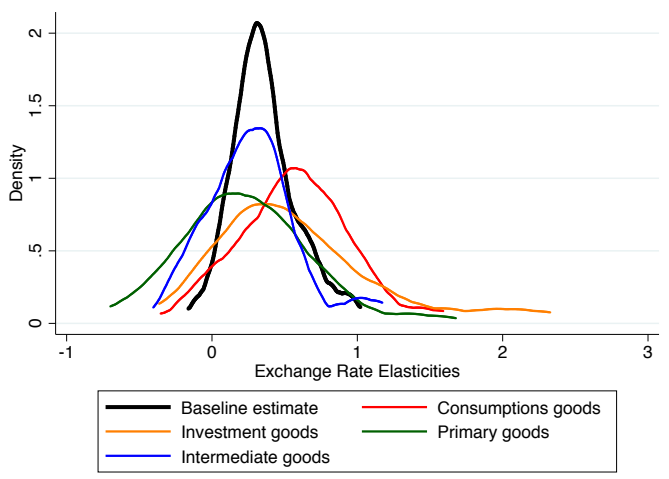

(c) Export volumes

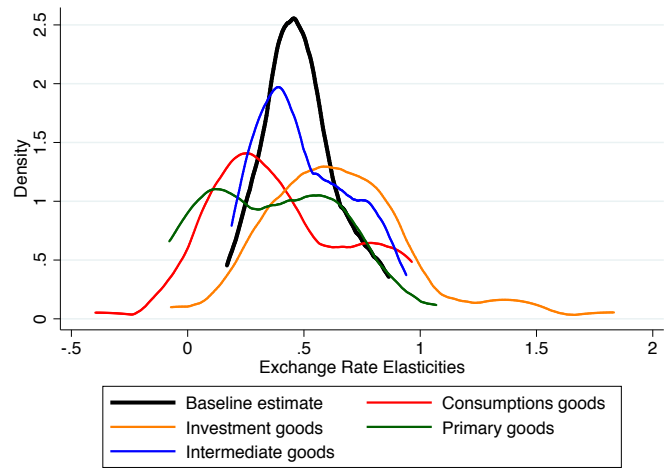

(b) Import prices

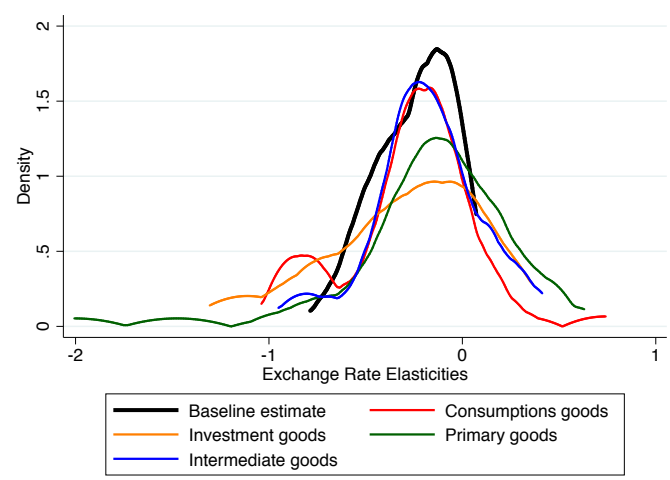

(d) Import volumes

Figure 9: Kernel distribution of estimated exchange rate elasticities across countries in each of the four sectors

in particular, investment, intermediate, consumption and primary goods. The regression specification for import prices in sector $s$ looks like the following:

$$
d \log \left(p_{i[j] k t}\right)=\alpha_{[j s]}-\beta_{[j s]} d \log \left(s_{i j t}\right)+f_{i[j] k}+e_{i j k t},
$$

where $\beta_{[j s]}$ is the exchange rate pass-through coefficient of sector $s$ in country $j$. To classify six-digit HS codes into the respective sectors, we use the Broad Economic Categories (BEC) of the United Nations. To better visualize the results, we plot the Kernel distribution of the different exchange rate estimates. Figure 9(a) and Figure 9(b) show the distribution for price, while Figure 9(c) and Figure 9(d) for quantity elasticities across countries. Note that in all four graphs the baseline estimates are closest to the estimates for intermediate goods suggesting that aggregate elasticities are mainly driven by trade in the intermediate good sector, which is the largest sector by covering almost $50 \%$ of world trade in our data. For the other sectors, the results are more mixed. While the median is broadly similar across sectors, the elasticities tend to be much more dispersed across countries, particularly for primary goods. In addition, we analyse to what extent the variation in the aggregate exchange rate elasticities can be explained by common sector-specific elasticities. To do so, we regress the coefficients obtained from equation 13 on sector $\left(f_{s}\right)$ and country $\left(f_{j}\right)$ fixed effects, i.e.,

$$
\hat{\beta}_{j s}=f_{s}+f_{j}+e_{j s},
$$


and calculate the share of variation explained by sectoral fixed effects. Overall, the results suggest that the aggregate response of the exchange rate elasticities is mainly driven by country fixed effects rather than by sectorspecific variation. The regression where sectoral fixed effects explain the most is the export quantity with $29 \%$, while country fixed effects explain $71 \% .^{14}$

Finally, we also experimented with unweighted regressions instead of weighted regressions. Unweighted regressions change the estimated coefficients significantly. In particular, the estimated pass-through coefficients for exports are higher and the ones for imports are lower (i.e., more pricing-to-market). Still, we prefer the weighted regression results as it is sensible to give more weight to price changes in categories and partner countries that have a high trading volume if we want our results to be comparable to those obtained using aggregate data. Another potential concern is that our definition of outliers might influence our results. Indeed, we dropped all those observations with price changes above $200 \%\left(-\log (1+2)<d \log \left(p_{i j k t}\right)<\log (1+2)\right)$. Instead of choosing a fixed cutoff of $200 \%$, we experimented also with throwing out observations that are in the top 1 percentile of the price changes in each product category for each exporting and importing country. The results are very similar to our baseline estimates. $^{15}$

\section{Conclusion}

This paper estimates exchange rate price and quantity elasticities for imports and exports for 51 countries. The analysis is based on a rich database of bilateral trade flows with 160 partner countries and about 5,000 different products. We present standard regressions and complement these baseline results with alternative specifications, building on the multidimensional panel structure of the data set. In particular, these alternative specifications allow us to explore the role of unobserved variables, such as marginal costs and competitor prices in the importing market. We also present a battery of robustness results, controlling for additional lags of the data, and additional control variables, in particular.

The main empirical results on this paper can be summarized as follows. First, our estimates indicate that exchange rate pass-through is incomplete for most countries, and that there is substantial heterogeneity in the reaction of export and import prices across countries. The estimates reveal that, on average, the exchange rate elasticity of export prices is higher in advanced economies than in emerging markets, suggesting that exporters from emerging-market economies have more market power than their counterparts in advanced economies. For import prices, we also find substantial heterogeneity across countries but no significant difference between emerging markets and advanced economies.

Second, our baseline trade quantity regressions yield elasticities in the range of $0.2-0.4$. Based on the estimated price and quantity exchange rate elasticities, the results imply that the Marshall-Lerner conditions are satisfied for all countries in the sample. This is largely because pass-through is incomplete in the majority of countries, while export prices in producer (exporter) currency react significantly to exchange rate changes (two results that are of course two sides of the same coin). As a result, the full Marshall-Lerner conditions (taking into account not only the reaction of trade volumes but also trade prices) are satisfied even though some of the exchange rate quantity elasticities are not significantly different from zero (especially on the import side). Cross-country differences in the reaction of the trade balance reflect to a large extent their openness to trade.

Third, controlling for time-varying country and product fixed effects substantially modifies the results and their interpretations. For export prices, the median exchange rate pass-through coefficient increases substantially.

\footnotetext{
${ }^{14}$ One concern is that the obtained result is self-evident since we only consider four sectors. Thus, we re-estimate equation 13 for each four-digit HS product code (1,250 categories) and calculate the explanative power of the sectoral variation with respect to the overall variation using equation 14. Again, we find that for all four regressions country fixed effects explain a much larger share than sectoral fixed effects. Detailed results are available upon request.

${ }^{15}$ We do not to report them in order to save space. Detailed results are available upon request.
} 
One possible interpretation is that this alternative specification controls for marginal costs and therefore focuses on the reaction of profit margins only, suggesting that a significant part of the reaction of export prices in producer currency comes from varying costs (associated, e.g., to imported costs). In the import price equation the alternative specification controls for time-varying conditions in the importing countries and in particular, local prices. This alternative specification also reduces the pass-through coefficient compared with the baseline (as foreign exporters take into account the reaction of local prices). Generally, turning to the fixed-effects equations reduces the dispersion of the coefficients, suggesting that controlling for unobserved variables removes a substantial source of cross-country heterogeneity. For the export and import quantity equations, the coefficients are also substantially modified when we turn to the alternative specifications.

Overall, these different specifications yield complementary insights on the issue of exchange rate elasticities. While the baseline specification is very close in spirit to the macro approach (the magnitude of these elasticities being correlated with existing macro studies), the fixed-effect approach goes one step further and helps disentange the different mechanisms at work when the exchange rate varies. From a policy perspective, the results suggest that exchange rate movements can play an important role in addressing global trade imbalances. 


\section{References}

Amiti, M., O. Itskhoki, And J. Konings (2014): "Importers, Exporters, and Exchange Rate Disconnect," American Economic Review, 104, 1942-78.

- (2016): "International shocks and domestic prices: how large are strategic complementarities?" NBER Working Papers, 22119.

Atkeson, A. And A. Burstein (2008): "Pricing-to-market, trade costs, and international relative prices," The American Economic Review, 98, 1998-2031.

Autr, R. A. (2015): "Exchange Rate Pass-Through, Domestic Competition, and Inflation: Evidence from the 2005-08 Revaluation of the Renminbi," Journal of Money, Credit and Banking, 47, 1617-1650.

Auer, R. A. And R. S. Schoenle (2016): "Market structure and exchange rate pass-through," Journal of International Economics, 98, 60-77.

BAKer, M. AND N. M. Fortin (2001): "Occupational gender composition and wages in Canada, 1987-1988," Canadian Journal of Economics/Revue canadienne d'économique, 34, 345-376.

Bas, M., T. Mayer, And M. Thoenig (2017): "From Micro to Macro: Demand, Supply, and Heterogeneity in the Trade Elasticity," Journal of International Economics, 108, 1-19, (lead article).

Berman, N., P. Martin, And T. Mayer (2012): "How do different exporters react to exchange rate changes?" The Quarterly Journal of Economics, 127, 437-492.

Burstein, A. And G. Gopinath (2014): "International prices and exchange rates," Handbook of International Economics, 4, 391-451.

BussiÈre, M. (2013): "Exchange Rate Pass-through to Trade Prices: The Role of Nonlinearities and Asymmetries," Oxford Bulletin of Economics and Statistics, 75, 731-758.

Bussière, M., G. Callegari, F. Ghironi, G. Sestieri, and N. Yamano (2013): "Estimating trade elasticities: Demand composition and the trade collapse of 2008-09," American Economic Journal: Macroeconomics, 5, 11851.

Bussière, M., S. Delle Chiaie, and T. A. Peltonen (2014): "Exchange Rate Pass-Through in the Global Economy: The Role of Emerging Market Economies," IMF Economic Review, 62, 146-178.

Campa, J. M. and L. S. Goldberg (2001): "Employment versus wage adjustment and the US dollar," Review of Economics and Statistics, 83, 477-489.

- (2005): "Exchange rate pass-through into import prices," Review of Economics and Statistics, 87, 679-690.

Corsetti, G. and L. Dedola (2005): "A macroeconomic model of international price discrimination," Journal of International Economics, 67, 129-155.

Corsetti, G., L. Dedola, And S. Leduc (2007): "Optimal monetary policy and the sources of local-currency price stability," in International dimensions of monetary policy, University of Chicago Press, 319-367.

Devereux, M., W. Dong, And B. Tomlin (2015): "Exchange Rate Pass-Through, Currency Invoicing and Trade Partners," Bank of Canada Working Paper, 2015-31. 
Feenstra, R. C., P. A. Luck, M. Obstfeld, And K. N. Russ (2014): "In search of the Armington elasticity," NBER Working Papers, 20063.

Fischer, S. (2015): "The Transmission of Exchange Rate Changes to Output and Inflation," Monetary Policy Implementation and Transmission in the Post-Crisis Period conference, Federal Reserve System, Washington, D.C.

Fitzgerald, D. And S. Haller (2014): "Exporters and shocks: Dissecting the international elasticity puzzle," NBER Working Papers, 19968.

ForBes, K. (2015): "Much ado about something important: How do exchange rate movements affect inflation?" Macro and Finance Research Group Annual Conference, Cardiff, England.

Garetto, S. (2016): "Firms' heterogeneity, incomplete information, and pass-through," Journal of International Economics, 101, 168-179.

Gaulier, G., A. Lahrèche-RÉvil, and I. MéJean (2008): "Exchange-rate pass-through at the product level," Canadian Journal of Economics/Revue canadienne d'économique, 41, 425-449.

Gaulier, G. And S. Zignago (2010): "BACI: International trade database at the product-level," CEPII Working Paper, 2010-23.

Gopinath, G. (2015): "The international price system," NBER Working Papers, 21646.

Gust, C., S. Leduc, And N. Sheets (2009): "The adjustment of global external balances: Does partial exchangerate pass-through to trade prices matter?" Journal of international Economics, 79, 173-185.

Head, K. And T. Mayer (2014): "Gravity Equations: Workhorse, Toolkit, and Cookbook," Handbook of international economics, 4.

Hooper, P., K. Johnson, and J. R. Marquez (2002): "Trade elasticities for the G-7 countries," The Economic Journal, 112, F377-F378.

Ihrig, J. E., M. Marazzi, And A. D. Rothenberg (2006): "Exchange-rate pass-through in the G-7 countries," FRB International Finance Discussion Paper, 851.

Imbs, J. AND I. MÉJeAn (2015): "Elasticity optimism," American Economic Journal: Macroeconomics, 7, 43-83.

Knetter, M. M. (1989): "Price discrimination by US and German exporters," The American Economic Review, 198-210.

Krugman, P. (1986): "Pricing to market when the exchange rate changes," Tech. rep., National Bureau of Economic Research.

Leigh, D., W. Lian, M. Poplawski-Ribeiro, and V. Tsyrennikov (2015): Exchange rates still matter for trade, vol. WEO October Chapter 3, International Monetary Fund.

Mantega, G. (2010): "Brazil in currency war," Financial Times, Interview.

Mishra, P. And A. Spilimbergo (2011): "Exchange rates and wages in an integrated world," American Economic Journal: Macroeconomics, 3, 53-84.

Mumtaz, H., O. Oomen, And J. Wang (2006): "Exchange rate pass-through into UK import prices," Bank of England working paper, 312 . 
Orcutt, G. H. (1950): "Measurement of price elasticities in international trade," The Review of Economics and Statistics, 32, 117-132.

Ossa, R. (2015): "Why trade matters after all?" Journal of International Economics, 97, 266-277.

PAGAN, A. (1984): "Econometric issues in the analysis of regressions with generated regressors," International Economic Review, 25, 221-247.

Redding, S. And A. J. Venables (2004): "Economic geography and international inequality," Journal of international Economics, 62, 53-82.

RuHL, K. J. (2008): "The international elasticity puzzle," unpublished paper, NYU.

Schmalensee, R. And P. L. Joskow (1986): "Estimated parameters as independent variables: An application to the costs of electric generating units," Journal of Econometrics, 31, 275-305.

Yellen, J. (2015): "Inflation Dynamics and Monetary Policy," Philip Gamble Memorial Lecture, University of Massachusetts, Amherst, Massachusetts. 


\section{Tables}

Table 1: Countries in the sample

\begin{tabular}{cccc}
\hline Country ISO Code & Country Name & Country ISO Code & Country Name \\
\hline ARG & Argentina & ISR & Israel \\
AUS & Australia & ITA & Italy \\
AUT & Austria & JPN & Japan \\
BEL & Belgium & KOR & South Korea \\
BRA & Brazil & LKA & Sri Lanka \\
CAN & Canada & MAR & Morocco \\
CHE & Switzerland & MEX & Mexico \\
CHL & Chile & NLD & Netherlands \\
CHN & China & NOR & Norway \\
COL & Columbia & NZL & New Zealand \\
CRI & Costa Rica & PAK & Pakistan \\
CZE & Czech Republic & PER & Peru \\
DEU & Germany & PHL & Philippines \\
DNK & Denmark & POL & Poland \\
EGY & Egypt & PRT & Portugal \\
ESP & Spain & RUS & Russia \\
FIN & Finland & SAU & Saudi Arabia \\
FRA & France & SGP & Singapore \\
GBR & United Kingdom & SWE & Sweden \\
GRC & Greece & THA & Thailand \\
GTM & Guatemala & TUN & Tunisia \\
HKG & Hong Kong & TUR & Turkey \\
HUN & Hungary & URY & Uruguay \\
IDN & Indonesia & USA & United States \\
IND & India & ZAF & South Africa \\
IRL & Ireland & & \\
& & &
\end{tabular}


Table 2: Summary statistics on exchange rate elasticities for export volumes and prices

\begin{tabular}{lccc}
\hline & Median & Mean & Std. Dev. \\
\hline Unweighted & & & \\
Price elasticity - baseline & 0.655 & 0.687 & 0.217 \\
Price elasticity - product-time fixed effects & 0.866 & 0.885 & 0.184 \\
Price elasticity - 2-way fixed effects & 0.570 & 0.576 & 0.226 \\
Quantity elasticity - baseline & 0.347 & 0.345 & 0.222 \\
Quantity elasticity - product-time fixed effects & 0.469 & 0.431 & 0.280 \\
Quantity elasticity - 2-way fixed effects & 0.364 & 0.353 & 0.250 \\
\hline Weighted by trade in 2012 $(X+M) \div 2$ & & & \\
Price elasticity - baseline & 0.704 & 0.711 & 0.177 \\
Price elasticity - product-time fixed effects & 0.897 & 0.902 & 0.130 \\
Price elasticity - 2-way fixed effects & 0.627 & 0.683 & 0.185 \\
Quantity elasticity - baseline & 0.348 & 0.359 & 0.188 \\
Quantity elasticity - product-time fixed effects & 0.450 & 0.418 & 0.205 \\
Quantity elasticity - 2-way fixed effects & 0.351 & 0.353 & 0.188 \\
\hline Advanced economies & & & \\
Price elasticity - baseline & 0.719 & 0.797 & 0.155 \\
Price elasticity - product-time fixed effects & 0.897 & 0.911 & 0.127 \\
Price elasticity - 2-way fixed effects & 0.631 & 0.664 & 0.178 \\
Quantity elasticity - baseline & 0.337 & 0.368 & 0.185 \\
Quantity elasticity - product-time fixed effects & 0.442 & 0.428 & 0.184 \\
Quantity elasticity - 2-way fixed effects & 0.370 & 0.353 & 0.169 \\
\hline Emerging-market economies & & & \\
Price elasticity - baseline & 0.592 & 0.597 & 0.252 \\
Price elasticity - product-time fixed effects & 0.837 & 0.878 & 0.224 \\
Price elasticity - 2-way fixed effects & 0.511 & 0.493 & 0.254 \\
Quantity elasticity - baseline & 0.356 & 0.315 & 0.257 \\
Quantity elasticity - product-time fixed effects & 0.495 & 0.458 & 0.350 \\
Quantity elasticity - 2-way fixed effects & 0.358 & 0.355 & 0.312 \\
\hline
\end{tabular}


Table 3: Summary statistics on exchange rate elasticities for import volumes and prices

\begin{tabular}{lccc}
\hline & Median & Mean & Std. Dev. \\
\hline Unweighted & & & \\
Price elasticity - baseline & 0.480 & 0.468 & 0.161 \\
Price elasticity - product-time fixed effects & 0.220 & 0.188 & 0.192 \\
Price elasticity - 2-way fixed effects & 0.682 & 0.625 & 0.192 \\
Quantity elasticity - baseline & -0.245 & -0.204 & 0.202 \\
Quantity elasticity - product-time fixed effects & -0.217 & -0.158 & 0.268 \\
Quantity elasticity - 2-way fixed effects & -0.520 & -0.447 & 0.233 \\
\hline Weighted by trade in 2012 $(X+M) \div 2$ & & & \\
Price elasticity - baseline & 0.452 & 0.429 & 0.161 \\
Price elasticity - product-time fixed effects & 0.178 & 0.166 & 0.129 \\
Price elasticity - 2-way fixed effects & 0.720 & 0.724 & 0.181 \\
Quantity elasticity - baseline & -0.166 & -0.126 & 0.157 \\
Quantity elasticity - product-time fixed effects & -0.172 & -0.132 & 0.155 \\
Quantity elasticity - 2-way fixed effects & -0.483 & -0.438 & 0.157 \\
\hline Advanced economies & & & \\
Price elasticity - baseline & 0.472 & 0.473 & 0.158 \\
Price elasticity - product-time fixed effects & 0.228 & 0.232 & 0.126 \\
Price elasticity - 2-way fixed effects & 0.692 & 0.662 & 0.196 \\
Quantity elasticity - baseline & -0.217 & -0.186 & 0.165 \\
Quantity elasticity - product-time fixed effects & -0.215 & -0.158 & 0.168 \\
Quantity elasticity - 2-way fixed effects & -0.473 & -0.438 & 0.140 \\
\hline Emerging-market economies & & & \\
Price elasticity - baseline & 0.487 & 0.462 & 0.167 \\
Price elasticity - product-time fixed effects & 0.212 & 0.164 & 0.242 \\
Price elasticity - 2-way fixed effects & 0.671 & 0.614 & 0.191 \\
Quantity elasticity - baseline & -0.271 & -0.223 & 0.232 \\
Quantity elasticity - product-time fixed effects & -0.219 & -0.150 & 0.341 \\
Quantity elasticity - 2-way fixed effects & -0.564 & -0.470 & 0.292 \\
\hline
\end{tabular}


Table 4: Estimates of exchange rate elasticities for export and import prices in the baseline specification

\begin{tabular}{|c|c|c|c|c|}
\hline & \multicolumn{2}{|c|}{ Export Prices } & \multicolumn{2}{|c|}{ Import Prices } \\
\hline & & & & \\
\hline ARG & & & & \\
\hline US & & & & \\
\hline UT & & & & \\
\hline EL & & & & \\
\hline RA & & & & \\
\hline AN & & & & \\
\hline $\mathrm{HE}$ & & & & \\
\hline HL & & & & \\
\hline $\mathrm{HN}$ & & & & \\
\hline $\mathrm{OL}$ & & & & \\
\hline CRI & & & & .174 \\
\hline $\mathrm{CZE}$ & & 0.0 & & \\
\hline $\mathrm{EU}$ & & & & \\
\hline NK & & & & \\
\hline GY & & 1 & & \\
\hline ESP & & 7 & & \\
\hline IN & & 0.0 & & \\
\hline RA & & 8 & & 0.042 \\
\hline BR & & 0.0 & & 0.044 \\
\hline $\mathrm{RC}$ & & 0.0 & k* & 0.132 \\
\hline ТМ & & 0.2 & 0.1 & 0.095 \\
\hline KG & * & 0.08 & & 0.056 \\
\hline UN & & 0.0 & & 0.096 \\
\hline $\mathrm{DN}$ & & 0.0 & & 0.087 \\
\hline ND & * & 0.0 & & 0.147 \\
\hline RL & & 0.1 & & 0.115 \\
\hline I & & 0.1 & * & 0.091 \\
\hline & & 0.0 & & 0.031 \\
\hline & & 0.0 & & \\
\hline I & & 0.0 & & \\
\hline I & & 0 & & \\
\hline 1 & & & & \\
\hline & & & & \\
\hline $\mathrm{I}$ & & . & & \\
\hline OP & & 0.1 & & \\
\hline NZL & & 0.0 & & \\
\hline PAF & & 0 & & \\
\hline PER & & 0.1 & & \\
\hline PHL & & 0.2 & & \\
\hline POL & & 0.0 & & \\
\hline PRT & & 0.0 & & .093 \\
\hline RUS & & 0.07 & 0.798 & 0.022 \\
\hline $\mathrm{SAU}$ & & 0.1 & & .163 \\
\hline SGP & $924^{* *}$ & 0.083 & & .078 \\
\hline SWE & & 0.0 & & .087 \\
\hline THA & * & 0.084 & $* *$ & 0.097 \\
\hline TUN & * & 0.132 & & .104 \\
\hline TUR & * & 0.046 & & 1.024 \\
\hline URY & 485 & .068 & & 0.094 \\
\hline US & & 6 & & 0.031 \\
\hline ZAF & & 0.051 & & 0.079 \\
\hline
\end{tabular}

Note: ER is the estimated coefficient of the exchange rate and SE is the corresponding standard error. 
Table 5: Estimates of exchange rate elasticities for export and import quantities in the baseline specification

\begin{tabular}{|c|c|c|c|c|c|c|c|c|}
\hline & \multicolumn{4}{|c|}{ Export Quantities } & \multicolumn{4}{|c|}{ Import Quantities } \\
\hline & ER & $(\mathrm{SE})$ & GDP & (SE) & ER & $(\mathrm{SE})$ & GDP & $(\mathrm{SE})$ \\
\hline ARG & .162 & 107 & 1 & 1.697 & -0.46 & 0 & & 0.158 \\
\hline AUS & $729^{* *}$ & 221 & 1.63 & 712 & -0.30 & .123 & & 0.644 \\
\hline AUT & $0.488^{* *}$ & 0.109 & 1.20 & 214 & 0.087 & .073 & & .208 \\
\hline BEL & $0.566^{* *}$ & 0.105 & 1.65 & 162 & 0.072 & & 1.50 & .241 \\
\hline BRA & $0.282^{* *}$ & 0.057 & 1.70 & 0.283 & $-0.229^{* *}$ & .047 & 0.02 & 0.655 \\
\hline $\mathrm{CAN}$ & 0.106 & 0.197 & 1.53 & 0.445 & -0.28 & & & .483 \\
\hline $\mathrm{CHE}$ & $0.623^{* *}$ & 0.117 & 1.41 & 0.329 & -0.362 & & & 0.379 \\
\hline CHL & 0.425 & 0.064 & 1.40 & 0.3 & -0.335 & .175 & 1.22 & 0.372 \\
\hline CHN & $0.616^{*}$ & 0.047 & 1.1 & 0.166 & 0.041 & 71 & & 0.482 \\
\hline $\mathrm{COL}$ & 0.267 & 0.147 & 1.3 & 0.517 & -0.597 & 1 & & 0.766 \\
\hline CRI & 0.631 & 0.331 & 1.1 & 0.752 & $-0.7 \varepsilon$ & 0.268 & & 0.982 \\
\hline CZE & $0.295^{* *}$ & 0.084 & 1.1 & 0.161 & $-0.277^{* *}$ & 0.070 & & 0.241 \\
\hline $\mathrm{DEU}$ & $0.35 \mathrm{~s}$ & 0.051 & 1.3 & 0.055 & -0.086 & 0 & & 0.184 \\
\hline DNK & $0.382^{* *}$ & 0.079 & 0.9 & 0.119 & -0.0 & 0 & & 0.211 \\
\hline EGY & 0.250 & 0.155 & 0.612 & 0.402 & -0.3 & 0.1 & & 0.382 \\
\hline ESP & $0.430^{* *}$ & 0.067 & 1.1 & 0.145 & -0.18 & 0.061 & & 0.222 \\
\hline FIN & $0.445^{* *}$ & 0.085 & 1.5 & 0.245 & -0.1 & $0.0^{7}-x-2$ & & 0.232 \\
\hline FRA & 0.413 & 0.055 & 0.86 & 0.202 & -0.20 & 0.06 & & 0.113 \\
\hline GBR & $0.149^{* *}$ & 0.050 & 1.321 & 0.147 & -0.139 & 0.085 & $1.2^{2}$ & 0.235 \\
\hline GRC & $0.383^{*}$ & 0.153 & 0.94 & 0.213 & -0.447 & 0.24 & 1.65 & 0.327 \\
\hline GTM & 0.300 & 0.233 & $0.179^{* *}$ & 0.049 & -0.181 & 0.167 & 1.820 & 0.963 \\
\hline HKG & 0.304 & 0.255 & 0.416 & 0.329 & $-0.384^{* *}$ & 0.099 & 0.3 & 1.000 \\
\hline HUN & $1.021^{* *}$ & 0.205 & $1.429^{* *}$ & 0.408 & 0.025 & 0.086 & $1.17 \mathrm{?}$ & 0.263 \\
\hline IDN & $0.364^{* *}$ & 0.095 & $0.604^{* *}$ & 0.224 & 0.002 & 0.148 & $0.891^{* *}$ & 0.231 \\
\hline IND & $0.340^{* *}$ & 0.091 & 0.912 & 0.114 & $-0.516^{*}$ & 0.199 & 2.0 & 2.409 \\
\hline IRL & 0.184 & 0.250 & 2.008 & 0.610 & -0.099 & 0.244 & 2.072 & 0.246 \\
\hline ISR & 0.078 & 0.264 & 1.78 & 0.475 & -0.53 & 0.117 & 1.4 & 0.916 \\
\hline ITA & $0.220^{* *}$ & 0.028 & 1.26 & 0.077 & $-0.300^{* *}$ & 0.049 & 1.36 & 0.132 \\
\hline JPN & $0.283^{* *}$ & 0.090 & 1.9 & 0.141 & -0.126 & 0.074 & $1.5^{\circ}$ & 0.359 \\
\hline KOR & $0.368^{* *}$ & 0.134 & 1.3 & 0.26 & -0.067 & 0.094 & 1.53 & 0.370 \\
\hline LKA & 0.217 & 0.144 & 1.3 & 0.414 & 0.0 & 0.1 & & 0.520 \\
\hline MAR & 163 & 0.122 & 1.3 & $0.2 ?$ & -0.581 & 0.195 & 0.52 & 0.158 \\
\hline MEX & .015 & 0.208 & & 0.4 & - & 0.1 & & 0.541 \\
\hline NLD & $0.562^{* *}$ & 0.072 & 1.3 & 0.10 & -0.28 & 0.089 & 1.9 & 0.207 \\
\hline NOR & 0.397 & 0.210 & 0.62 & 0.229 & - & 0.1 & 0.48 & 0.127 \\
\hline NZL & $0.223^{* *}$ & 0.052 & 0.75 & 0.174 & $-0.428^{* *}$ & 0.1 & 1.6 & 1.684 \\
\hline PAK & $0.604^{* *}$ & 0.131 & 1.597 & 0.239 & -0.47 & 0.231 & 1.4 & 1.203 \\
\hline PER & $0.345^{*}$ & 0.158 & $1.132^{* *}$ & 0.364 & $-0.633^{* *}$ & 0.201 & $1.376^{* *}$ & 0.242 \\
\hline PHL & $0.879^{* *}$ & 0.321 & 944 & 2.388 & -0.12 & 0.142 & 0.6 & 0.388 \\
\hline POL & $0.313^{* *}$ & 0.077 & $1.730^{* *}$ & 0.242 & $-0.255^{* *}$ & 0.051 & $1.271^{* *}$ & 0.262 \\
\hline PRT & $0.177^{*}$ & 0.078 & $1.034^{* *}$ & 0.113 & $-0.351^{* *}$ & 0.073 & $1.286^{* *}$ & 0.214 \\
\hline RUS & 0.107 & 0.082 & $0.756^{* *}$ & 0.203 & $-0.452^{* *}$ & 0.054 & $0.946^{* *}$ & 0.137 \\
\hline SAU & $0.844^{* *}$ & 0.174 & $2.023^{*}$ & 0.779 & -0.043 & 0.192 & $0.598^{* *}$ & 0.203 \\
\hline SGP & $0.364^{*}$ & 0.136 & 0.568 & 0.518 & 0.000 & 0.113 & 0.003 & 0.253 \\
\hline SWE & -0.009 & 0.075 & $1.697^{* *}$ & 0.135 & $-0.487^{* *}$ & 0.079 & $2.036^{* *}$ & 0.260 \\
\hline THA & $0.316^{*}$ & 0.126 & $0.938^{* *}$ & 0.227 & -0.171 & 0.136 & $1.591^{* *}$ & 0.205 \\
\hline TUN & 0.119 & 0.179 & 1.310 & 0.728 & -0.218 & 0.113 & 0.099 & 0.154 \\
\hline TUR & $0.461^{* *}$ & 0.031 & $1.391^{* *}$ & 0.131 & 0.005 & 0.046 & $1.533^{* *}$ & 0.160 \\
\hline URY & $0.701^{* *}$ & 0.157 & .313 & 0.671 & -0.097 & 0.164 & 0.649 & 0.327 \\
\hline USA & $0.192^{* *}$ & 0.057 & $0.694^{* *}$ & 0.115 & -0.094 & 0.051 & $1.761^{* *}$ & 0.556 \\
\hline $\mathrm{ZAF}$ & $0.286^{* *}$ & 0.089 & $1.172^{*}$ & 0.516 & $-0.158^{*}$ & 0.060 & 1.317 & 1.208 \\
\hline
\end{tabular}

Note: ER is the estimated coefficient of the exchange rate, GDP the coefficient of GDP in the importing country and SE is the corresponding standard error. 
Table 6: Estimates of exchange rate elasticities for export and import prices with product-time fixed effects

\begin{tabular}{|c|c|c|c|c|}
\hline & $\begin{array}{c}\text { Export } \\
\text { ER }\end{array}$ & $\begin{array}{c}\text { Prices } \\
\quad(\mathrm{SE})\end{array}$ & $\begin{array}{c}\text { Import } \\
\text { ER }\end{array}$ & $\begin{array}{c}\text { Prices } \\
\quad(\mathrm{SE})\end{array}$ \\
\hline ARG & 54 & 195 & ..069 & \\
\hline US & 795 & & ** & \\
\hline UT & ** & .079 & $* *$ & \\
\hline BEL & * & 0.054 & 100 & \\
\hline BRA & * & 0.045 & 0.0 & \\
\hline $\mathrm{AN}$ & * & 60 & .075 & \\
\hline $\mathrm{HE}$ & & 0.0 & & \\
\hline HL & & 0.0 & & 267 \\
\hline HN & * & 0.050 & & \\
\hline $\mathrm{OL}$ & * & 0.110 & 140 & .077 \\
\hline CRI & * & 0.168 & 0.937 & .565 \\
\hline CZE & * & 0.041 & 0.19 & 0.052 \\
\hline $\mathrm{EU}$ & & 0.022 & .17 & 0.026 \\
\hline NK & * & 0.053 & 0.23 & .036 \\
\hline GY & * & 0.091 & -0. & 0.061 \\
\hline SP & * & 0.0 & & \\
\hline & & 0.0 & & \\
\hline RA & & 0.0 & & \\
\hline $3 R$ & & & & \\
\hline $\mathrm{C}$ & & & & \\
\hline $\mathrm{M}$ & & & & \\
\hline & & & & \\
\hline & & & & \\
\hline & & & & \\
\hline D & & & & \\
\hline $2 \mathrm{~L}$ & & & & \\
\hline $\mathrm{R}$ & & & & \\
\hline & & & & \\
\hline & & & & \\
\hline DR & & & & \\
\hline $\mathrm{A}$ & & & & \\
\hline $\mathrm{AR}$ & & & & \\
\hline EX & & & & \\
\hline $\mathrm{D}$ & & & & \\
\hline OR & & & & \\
\hline IZL & & & & \\
\hline AK & & & & \\
\hline PER & & & & 54 \\
\hline HL & & & & 0.137 \\
\hline POL & & & & 0.030 \\
\hline PRT & & & & 0.075 \\
\hline RUS & & & & 0.032 \\
\hline SAU & & & & \\
\hline SGP & & 0.159 & & 0.110 \\
\hline SWE & & 0.046 & & 0.073 \\
\hline THA & & & & 0.118 \\
\hline TUN & ** & 0.154 & & 0.051 \\
\hline TUR & & 0.027 & $0.140^{* *}$ & 0.042 \\
\hline URY & $.676^{* *}$ & 0.187 & $-100-$ & 0.144 \\
\hline USA & $852^{* *}$ & 0.06 & .117 & 0.063 \\
\hline ZAF & $0.841^{* *}$ & 0.117 & 0.167 & 0.087 \\
\hline
\end{tabular}

Note: ER is the estimated coefficient of the exchange rate and SE is the corresponding standard error. 
Table 7: Exchange rate elasticities for export and import quantities with product-time fixed effects

\begin{tabular}{|c|c|c|c|c|c|c|}
\hline & \multicolumn{4}{|c|}{ Export Quantities } & \multicolumn{2}{|c|}{ Import Quantities } \\
\hline & ER & $(\mathrm{SE})$ & GDP & $(\mathrm{SE})$ & ER & $(\mathrm{SE})$ \\
\hline ARG & 0.369 & 0.264 & 1.281 & 1.697 & 0.030 & 0.175 \\
\hline AUS & $0.951^{*}$ & 0.446 & $1.639^{*}$ & 0.712 & -0.127 & 0.104 \\
\hline AUT & $0.480^{* *}$ & 0.099 & $1.208^{* *}$ & 0.214 & -0.214 & 0.109 \\
\hline BEL & $0.529 * *$ & 0.115 & $1.658^{* *}$ & 0.162 & -0.107 & 0.086 \\
\hline BRA & $0.588^{* *}$ & 0.094 & $1.705^{* *}$ & 0.283 & 0.131 & 0.113 \\
\hline CAN & $0.282^{* *}$ & 0.085 & $1.533^{* *}$ & 0.445 & -0.113 & 0.149 \\
\hline CHE & $0.405^{* *}$ & 0.111 & $1.416^{* *}$ & 0.329 & -0.693 & 0.500 \\
\hline CHL & $0.586^{* *}$ & 0.068 & $1.409^{* *}$ & 0.316 & -0.325 & 0.265 \\
\hline $\mathrm{CHN}$ & $0.418^{* *}$ & 0.061 & $1.114^{* *}$ & 0.166 & -0.036 & 0.093 \\
\hline COL & $0.445^{* *}$ & 0.153 & $1.319^{*}$ & 0.517 & $-0.253^{*}$ & 0.112 \\
\hline CRI & $0.329^{*}$ & 0.138 & 1.157 & 0.752 & $-1.309^{*}$ & 0.632 \\
\hline CZE & $0.574^{* *}$ & 0.082 & $1.190^{* *}$ & 0.161 & -0.072 & 0.086 \\
\hline DEU & $0.385^{* *}$ & 0.042 & $1.307^{* *}$ & 0.055 & $-0.140^{* *}$ & 0.040 \\
\hline DNK & $0.439^{* *}$ & 0.083 & $0.911^{* *}$ & 0.119 & -0.080 & 0.074 \\
\hline EGY & 0.560 & 0.578 & 0.612 & 0.402 & -0.220 & 0.191 \\
\hline ESP & $0.502^{* *}$ & 0.061 & $1.174^{* *}$ & 0.145 & $-0.187^{*}$ & 0.090 \\
\hline FIN & $0.378^{* *}$ & 0.076 & $1.538^{* *}$ & 0.245 & -0.155 & 0.098 \\
\hline FRA & $0.402^{* *}$ & 0.047 & $0.861^{* *}$ & 0.202 & $-0.175^{* *}$ & 0.062 \\
\hline GBR & $0.391^{* *}$ & 0.082 & $1.321^{* *}$ & 0.147 & -0.086 & 0.049 \\
\hline GRC & $0.455^{* *}$ & 0.156 & $0.945^{* *}$ & 0.213 & -0.402 & 0.222 \\
\hline GTM & -0.046 & 0.266 & $0.179^{* *}$ & 0.049 & -0.107 & 0.271 \\
\hline HKG & 0.310 & 0.261 & 0.416 & 0.329 & $-0.463^{* *}$ & 0.165 \\
\hline HUN & $0.930^{* *}$ & 0.187 & $1.429 * *$ & 0.408 & -0.042 & 0.154 \\
\hline IDN & $0.365^{* *}$ & 0.127 & $0.604^{* *}$ & 0.224 & -0.565 & 0.394 \\
\hline IND & $0.480^{* *}$ & 0.069 & $0.912^{* *}$ & 0.114 & -0.208 & 0.162 \\
\hline IRL & 0.013 & 0.306 & $2.008^{* *}$ & 0.610 & $-0.386^{*}$ & 0.191 \\
\hline ISR & $0.431^{* *}$ & 0.140 & $1.788^{* *}$ & 0.475 & $-0.569 * *$ & 0.141 \\
\hline ITA & $0.428^{* *}$ & 0.028 & $1.262^{* *}$ & 0.077 & $-0.269 * *$ & 0.044 \\
\hline JPN & $0.650^{* *}$ & 0.082 & $1.913^{* *}$ & 0.141 & -0.010 & 0.041 \\
\hline KOR & $0.739^{* *}$ & 0.098 & $1.353^{* *}$ & 0.267 & $-0.206^{* *}$ & 0.067 \\
\hline LKA & 0.202 & 0.132 & $1.380^{* *}$ & 0.414 & 0.558 & 0.445 \\
\hline MAR & $0.243^{*}$ & 0.113 & $1.313^{* *}$ & 0.293 & $-0.480^{*}$ & 0.188 \\
\hline MEX & $0.646^{* *}$ & 0.210 & $1.636^{* *}$ & 0.468 & $-0.450^{* *}$ & 0.133 \\
\hline NLD & $0.464^{* *}$ & 0.066 & $1.356^{* *}$ & 0.106 & $-0.251^{*}$ & 0.099 \\
\hline NOR & 0.323 & 0.194 & $0.626^{* *}$ & 0.229 & -0.158 & 0.101 \\
\hline NZL & $0.348^{* *}$ & 0.114 & $0.759^{* *}$ & 0.174 & 0.009 & 0.178 \\
\hline PAK & $0.743^{* *}$ & 0.213 & $1.597^{* *}$ & 0.239 & $-0.453^{*}$ & 0.202 \\
\hline PER & 0.036 & 0.159 & $1.132^{* *}$ & 0.364 & $-0.810^{*}$ & 0.323 \\
\hline PHL & $1.494^{* *}$ & 0.409 & 0.944 & 2.388 & -0.068 & 0.170 \\
\hline POL & $0.807^{* *}$ & 0.067 & $1.730^{* *}$ & 0.242 & $-0.282^{* *}$ & 0.085 \\
\hline PRT & $0.204^{*}$ & 0.093 & $1.034^{* *}$ & 0.113 & $-0.205^{*}$ & 0.097 \\
\hline RUS & -0.010 & 0.066 & $0.756^{* *}$ & 0.203 & $-0.175^{* *}$ & 0.049 \\
\hline $\mathrm{SAU}$ & $1.095^{* *}$ & 0.130 & $2.023^{*}$ & 0.779 & -0.091 & 0.263 \\
\hline SGP & $0.585^{* *}$ & 0.168 & 0.568 & 0.518 & -0.132 & 0.141 \\
\hline SWE & $0.666^{* *}$ & 0.115 & $1.697^{* *}$ & 0.135 & -0.147 & 0.077 \\
\hline THA & 0.204 & 0.156 & $0.938^{* *}$ & 0.227 & -0.126 & 0.123 \\
\hline TUN & 0.120 & 0.223 & 1.310 & 0.728 & -0.115 & 0.163 \\
\hline TUR & $0.808^{* *}$ & 0.079 & $1.391^{* *}$ & 0.131 & $-0.237^{*}$ & 0.103 \\
\hline URY & 0.471 & 0.288 & 1.313 & 0.671 & 0.004 & 0.197 \\
\hline USA & $0.300^{* *}$ & 0.064 & $0.694^{* *}$ & 0.115 & -0.120 & 0.064 \\
\hline $\mathrm{ZAF}$ & 0.405 & 0.209 & $1.172^{*}$ & 0.516 & 0.014 & 0.183 \\
\hline
\end{tabular}

Note: ER is the estimated coefficient of the exchange rate, GDP the coefficient of GDP in the importing country and $\mathrm{SE}$ is the corresponding standard error. 
Table 8: Estimates of exchange rate elasticities for export and import prices in the 2-step approach

\begin{tabular}{|c|c|c|c|c|}
\hline & \multicolumn{2}{|c|}{ Export Prices } & \multicolumn{2}{|c|}{ Import Prices } \\
\hline & & & & \\
\hline $\mathrm{RG}$ & & & & \\
\hline JS & & & & \\
\hline UT & & & & \\
\hline EL & & & & \\
\hline RA & & & & \\
\hline AN & & & & \\
\hline $\mathrm{CHE}$ & & & & \\
\hline CHL & & & & \\
\hline HN & & & & \\
\hline $\mathrm{OL}$ & & & & \\
\hline RI & & & & \\
\hline $\mathrm{CZE}$ & & 0.0 & & \\
\hline DEU & & & & \\
\hline NK & & 1 & & \\
\hline GY & & 5 & & \\
\hline ESP & & 9 & & \\
\hline IN & & 0.0 & & \\
\hline FRA & & 0.0 & & \\
\hline $\mathrm{BR}$ & & 0.0 & & 0.038 \\
\hline $\mathrm{RC}$ & & 0.110 & & 0.209 \\
\hline TM & & 0.152 & & 0.151 \\
\hline KG & 0. & 0.076 & & 0.082 \\
\hline UN & 0. & 0.1 & & 0.110 \\
\hline $\mathrm{DN}$ & -0.0 & 0.0 & & 0.208 \\
\hline ND & * & 0.0 & & 0.224 \\
\hline$R \mathrm{~L}$ & & 0.1 & & 0.154 \\
\hline I & & 0.1 & & 0.182 \\
\hline & & 0.0 & & \\
\hline & & 0 & & \\
\hline I & & & & \\
\hline I & & 0.1 & & \\
\hline 1 & & & & \\
\hline 1 & & & & \\
\hline 1 & & & & \\
\hline $\mathrm{OH}$ & & & & \\
\hline NZI & & & & \\
\hline PAF & & & & \\
\hline PER & * & 0 & & \\
\hline PHL & & 0 & & \\
\hline POL & * & 0.0 & & \\
\hline PR] & * & 0.0 & & .085 \\
\hline RUS & $493^{* *}$ & 0.052 & & .043 \\
\hline $\mathrm{SAU}$ & & 0.10 & & .169 \\
\hline SGP & $944^{* *}$ & 0.108 & & .167 \\
\hline SWE & & 0.043 & & .069 \\
\hline THA & * & $0.0 \leqq$ & & .114 \\
\hline TUN & * & 0.150 & & .116 \\
\hline TUR & 375 & 0.034 & & .077 \\
\hline URY & 46 & 30 & & \\
\hline US & & & & 0.053 \\
\hline ZAF & 0.339 & 0.094 & $0.726^{* *}$ & 0.154 \\
\hline
\end{tabular}

Note: ER is the estimated coefficient of the exchange rate and SE is the corresponding standard error. 
Table 9: Estimates of exchange rate elasticities for export and import quantities in the 2-step approach

\begin{tabular}{|c|c|c|c|c|}
\hline & \multicolumn{2}{|c|}{ Export Quantities } & \multicolumn{2}{|c|}{ Import Quantities } \\
\hline & ER & $(\mathrm{SE})$ & ER & $(\mathrm{SE})$ \\
\hline ARG & 0.264 & 0.242 & $-0.842^{* *}$ & 0.148 \\
\hline AUS & $0.911^{*}$ & 0.412 & $-0.476^{* *}$ & 0.079 \\
\hline AUT & $0.333^{* *}$ & 0.100 & $-0.562^{* *}$ & 0.081 \\
\hline BEL & $0.487^{* *}$ & 0.107 & $-0.438^{* *}$ & 0.077 \\
\hline BRA & $0.500^{* *}$ & 0.086 & $-0.285^{* *}$ & 0.074 \\
\hline CAN & $0.256^{* *}$ & 0.093 & $-0.365^{*}$ & 0.150 \\
\hline CHE & $0.417^{* *}$ & 0.102 & -0.638 & 0.335 \\
\hline CHL & $0.269^{*}$ & 0.107 & $-0.646^{* *}$ & 0.213 \\
\hline $\mathrm{CHN}$ & $0.310^{* *}$ & 0.058 & $-0.405^{* *}$ & 0.100 \\
\hline COL & $0.223^{*}$ & 0.086 & $-0.576^{* *}$ & 0.107 \\
\hline CRI & -0.133 & 0.285 & $-1.521^{*}$ & 0.580 \\
\hline CZE & $0.494^{* *}$ & 0.077 & $-0.288^{* *}$ & 0.106 \\
\hline DEU & $0.353^{* *}$ & 0.036 & $-0.420^{* *}$ & 0.040 \\
\hline DNK & $0.379^{* *}$ & 0.091 & $-0.428 * *$ & 0.083 \\
\hline EGY & 0.652 & 0.564 & $-0.467^{* *}$ & 0.145 \\
\hline ESP & $0.448^{* *}$ & 0.057 & $-0.492^{* *}$ & 0.091 \\
\hline FIN & $0.333^{* *}$ & 0.074 & $-0.262 * *$ & 0.090 \\
\hline FRA & $0.363^{* *}$ & 0.041 & $-0.438^{* *}$ & 0.069 \\
\hline GBR & $0.343^{* *}$ & 0.078 & $-0.447^{* *}$ & 0.048 \\
\hline GRC & $0.402^{*}$ & 0.151 & $-0.672^{* *}$ & 0.136 \\
\hline GTM & -0.131 & 0.222 & -0.443 & 0.242 \\
\hline HKG & 0.195 & 0.248 & $-0.774^{* *}$ & 0.098 \\
\hline HUN & $0.566^{*}$ & 0.222 & $-0.248^{*}$ & 0.121 \\
\hline IDN & -0.074 & 0.119 & $-0.809 *$ & 0.321 \\
\hline IND & $0.408^{* *}$ & 0.068 & $-0.416^{*}$ & 0.182 \\
\hline IRL & -0.080 & 0.286 & $-0.603^{* *}$ & 0.205 \\
\hline ISR & $0.315^{*}$ & 0.142 & $-0.713^{* *}$ & 0.155 \\
\hline ITA & $0.430^{* *}$ & 0.029 & $-0.527^{* *}$ & 0.048 \\
\hline JPN & $0.369^{* *}$ & 0.060 & $-0.158^{*}$ & 0.060 \\
\hline KOR & $0.199^{* *}$ & 0.032 & $-0.378^{* *}$ & 0.085 \\
\hline LKA & $0.220^{*}$ & 0.106 & -0.156 & 0.127 \\
\hline MAR & 0.184 & 0.112 & $-0.742^{* *}$ & 0.197 \\
\hline MEX & $0.401^{*}$ & 0.185 & $-0.864^{* *}$ & 0.155 \\
\hline NLD & $0.435^{* *}$ & 0.067 & $-0.549^{* *}$ & 0.078 \\
\hline NOR & 0.330 & 0.218 & $-0.363^{* *}$ & 0.110 \\
\hline NZL & $0.341^{* *}$ & 0.114 & $-0.404^{*}$ & 0.159 \\
\hline PAK & $0.679^{* *}$ & 0.205 & $-0.686^{* *}$ & 0.187 \\
\hline PER & 0.073 & 0.274 & $-1.000^{* *}$ & 0.301 \\
\hline PHL & $0.630^{*}$ & 0.292 & $-0.423^{*}$ & 0.175 \\
\hline POL & $0.756^{* *}$ & 0.068 & $-0.472^{* *}$ & 0.080 \\
\hline PRT & $0.330^{*}$ & 0.131 & $-0.340 * *$ & 0.106 \\
\hline RUS & -0.181 & 0.095 & $-0.795^{* *}$ & 0.068 \\
\hline SAU & $0.937^{* *}$ & 0.099 & $-0.620^{* *}$ & 0.184 \\
\hline SGP & $0.530^{* *}$ & 0.155 & $-0.417^{* *}$ & 0.105 \\
\hline SWE & $0.566^{* *}$ & 0.098 & $-0.399^{* *}$ & 0.074 \\
\hline THA & 0.112 & 0.125 & $-0.406^{* *}$ & 0.150 \\
\hline TUN & 0.165 & 0.208 & $-0.407^{* *}$ & 0.147 \\
\hline TUR & $0.876^{* *}$ & 0.083 & $-0.506^{* *}$ & 0.074 \\
\hline URY & 0.657 & 0.408 & $-0.386^{*}$ & 0.158 \\
\hline USA & $0.257^{* *}$ & 0.059 & $-0.568^{* *}$ & 0.035 \\
\hline $\mathrm{ZAF}$ & $0.442^{*}$ & 0.187 & -0.264 & 0.430 \\
\hline
\end{tabular}

Note: ER is the estimated coefficient of the exchange rate and SE is the corresponding standard error. 
Table 10: Trade openness and effect of a 1\% depreciation of the exchange rate on net exports over GDP

\begin{tabular}{|c|c|c|c|}
\hline & Exports over GDP & Imports over GDP & Effect on Net Exports \\
\hline ARG & 0.174 & 0.148 & 0.124 \\
\hline AUS & 0.195 & 0.204 & 0.177 \\
\hline AUT & 0.507 & 0.475 & 0.139 \\
\hline BEL & 0.762 & 0.745 & 0.320 \\
\hline BRA & 0.107 & 0.118 & 0.039 \\
\hline CAN & 0.291 & 0.310 & 0.095 \\
\hline CHE & 0.642 & 0.535 & 0.340 \\
\hline CHL & 0.381 & 0.317 & 0.152 \\
\hline CHN & 0.262 & 0.232 & 0.097 \\
\hline COL & 0.159 & 0.178 & 0.090 \\
\hline CRI & 0.382 & 0.409 & 0.589 \\
\hline CZE & 0.662 & 0.631 & 0.303 \\
\hline DEU & 0.423 & 0.371 & 0.107 \\
\hline DNK & 0.497 & 0.436 & 0.220 \\
\hline EGY & 0.213 & 0.266 & 0.157 \\
\hline ESP & 0.255 & 0.268 & 0.118 \\
\hline FIN & 0.387 & 0.374 & 0.110 \\
\hline FRA & 0.260 & 0.279 & 0.083 \\
\hline GBR & 0.287 & 0.311 & 0.030 \\
\hline GRC & 0.221 & 0.307 & 0.062 \\
\hline GTM & 0.258 & 0.363 & 0.075 \\
\hline HKG & 2.194 & 2.135 & 0.798 \\
\hline HUN & 0.826 & 0.773 & 0.418 \\
\hline IDN & 0.243 & 0.224 & 0.184 \\
\hline IND & 0.220 & 0.263 & 0.119 \\
\hline IRL & 0.957 & 0.782 & 0.679 \\
\hline ISR & 0.350 & 0.330 & 0.036 \\
\hline ITA & 0.252 & 0.271 & 0.065 \\
\hline JPN & 0.152 & 0.140 & 0.026 \\
\hline KOR & 0.494 & 0.462 & 0.154 \\
\hline LKA & 0.224 & 0.307 & 0.059 \\
\hline MAR & 0.332 & 0.431 & 0.181 \\
\hline MEX & 0.299 & 0.311 & 0.098 \\
\hline NLD & 0.720 & 0.636 & 0.423 \\
\hline NOR & 0.398 & 0.286 & 0.029 \\
\hline NZL & 0.305 & 0.282 & 0.162 \\
\hline PAK & 0.135 & 0.194 & 0.147 \\
\hline PER & 0.266 & 0.235 & 0.173 \\
\hline PHL & 0.348 & 0.366 & 0.160 \\
\hline POL & 0.405 & 0.423 & 0.237 \\
\hline PRT & 0.299 & 0.374 & 0.108 \\
\hline RUS & 0.292 & 0.211 & 0.107 \\
\hline SAU & 0.497 & 0.331 & 0.570 \\
\hline SGP & 1.993 & 1.728 & 0.545 \\
\hline SWE & 0.462 & 0.407 & 0.120 \\
\hline THA & 0.713 & 0.639 & 0.481 \\
\hline TUN & 0.501 & 0.548 & 0.120 \\
\hline TUR & 0.212 & 0.268 & 0.058 \\
\hline URY & 0.263 & 0.253 & 0.226 \\
\hline USA & 0.124 & 0.158 & 0.028 \\
\hline ZAF & 0.286 & 0.274 & 0.148 \\
\hline
\end{tabular}




\section{Appendix}

To show that the import and the export exchange rate pass-through are linked, consider the following simplified example. Suppose there are three countries: France, the United Kingdom and the United States. Based on equation 5, we can write the import exchange rate pass-through for the United States as follows:

$$
\log \left(\frac{p_{U S, i, t}}{p_{U S, i, t-1}}\right)=\beta_{U S}^{M} \log \left(\frac{s_{U S, i, t}}{s_{U S, i, t-1}}\right)
$$

where $p_{U S, i, t}$ is the import price of the United States from exporter $i$ at the time $\mathrm{t}$ and $\beta_{U S}^{M}$ is the import price elasticity. Equivalently, we can write the change in the import price to the United States as a function of the export price elasticity of all $i$ countries, i.e., France and the United Kingdom. Consider the export price of France to the United States in US dollars:

$$
\log \left(\frac{p_{U S, F R, t}}{p_{U S, F R, t-1}}\right)=\beta_{F R}^{X} \log \left(\frac{s_{U S, F R, t}}{s_{U S, F R, t-1}}\right)
$$

Then the import price of the United States can be written as the trade-weighted average of the changes in the bilteral import prices with France and the bilateral import prices with the United Kingdom:

$w_{U S, F R, t} \log \left(\frac{p_{U S, F R, t}}{p_{U S, F R, t-1}}\right)+w_{U S, U K, t} \log \left(\frac{p_{U S, U K, t}}{p_{U S, U K, t-1}}\right)=\beta_{U S}^{M}\left(w_{U S, F R, t} \log \left(\frac{s_{U S, F R, t}}{s_{U S, F R, t-1}}\right)+w_{U S, U K, t} \log \left(\frac{s_{U S, U K, t}}{s_{U S, U K, t-1}}\right)\right)$,

where $w_{U S, i, t}$ is the import share of country $i$ in total US imports. Substituting the equation of the export elasticity into the import elasticity, we get:

$w_{U S, F R, t} \beta_{F R}^{X} \log \left(\frac{s_{U S, F R, t}}{s_{U S, F R, t-1}}\right)+w_{U S, U K, t} \beta_{U K}^{X} \log \left(\frac{s_{U S, U K, t}}{s_{U S, U K, t-1}}\right)=\beta_{U S}^{M}\left(w_{U S, F R, t} \log \left(\frac{s_{U S, F R, t}}{s_{U S, F R, t-1}}\right)+w_{U S, U K, t} \log \left(\frac{s_{U S, U K, t}}{s_{U S, U K, t-1}}\right)\right)$.

Thus, the import pass-through coefficient is a weighted average of all export pass-through coefficients of all trading partners. More generally, we can write the link between the import and elasticity for an arbitrary number of trading partners $J$ :

$$
\prod_{j=1}^{J}\left(\frac{s_{U S, j, t}}{s_{U S, j, t-1}}\right)^{w_{U S, j, t} \beta_{j}^{X}}=\left(\prod_{j=1}^{J}\left(\frac{s_{U S, j, t}}{s_{U S, j, t-1}}\right)^{w_{U S, j, t}}\right)^{\beta_{U S}^{M}}
$$

Next, suppose that the US dollar depreciates by $10 \%$ against all other currencies, i.e., $\frac{s_{U S, j, t}}{s_{U S, j, t-1}}=1.1 \forall j$, then $\sum_{j=1}^{J} w_{U S, j, t} \beta_{j}^{X}=\beta_{U S}^{M}$ and the import pass-through is an arithmetic mean of the export pass-through coefficient of trading partners. 
Table 11: Estimates of exchange rate elasticities for export prices with inflation as control variable

\begin{tabular}{|c|c|c|c|c|c|c|}
\hline & \multicolumn{6}{|c|}{ Export Prices } \\
\hline & ER & $(\mathrm{SE})$ & Inflation - Exp. & (SE) & Inflation - Imp. & (SE) \\
\hline ARG & 0.113 & 0.101 & $0.000^{* *}$ & 0.000 & $0.374^{*}$ & 0.147 \\
\hline AUS & 0.215 & 0.322 & $0.690^{*}$ & 0.326 & 0.946 & 1.025 \\
\hline AUT & $0.924^{* *}$ & 0.109 & -0.129 & 0.071 & $0.561^{* *}$ & 0.155 \\
\hline BEL & $0.767^{* *}$ & 0.064 & 0.454 & 0.727 & $0.165^{*}$ & 0.081 \\
\hline BRA & $0.537^{* *}$ & 0.056 & 0.027 & 0.181 & $0.649^{* *}$ & 0.116 \\
\hline CAN & $0.482^{* *}$ & 0.122 & 0.178 & 0.231 & 0.655 & 0.533 \\
\hline CHE & $0.809^{* *}$ & 0.079 & $-0.625^{* *}$ & 0.128 & -0.181 & 0.160 \\
\hline CHL & $1.043^{* *}$ & 0.160 & -1.019 & 0.737 & -0.546 & 0.313 \\
\hline $\mathrm{CHN}$ & $0.845^{* *}$ & 0.032 & $0.000^{* *}$ & 0.000 & -0.149 & 0.150 \\
\hline COL & $0.651^{* *}$ & 0.141 & 0.130 & 0.212 & 0.884 & 0.590 \\
\hline CRI & 0.361 & 0.256 & 0.603 & 0.535 & -0.200 & 0.166 \\
\hline CZE & $0.589^{* *}$ & 0.050 & 0.251 & 0.129 & $0.327^{* *}$ & 0.065 \\
\hline DEU & $0.829^{* *}$ & 0.027 & $0.174^{* *}$ & 0.046 & $0.119^{* *}$ & 0.029 \\
\hline DNK & $0.681^{* *}$ & 0.074 & $0.269^{*}$ & 0.116 & 0.221 & 0.131 \\
\hline EGY & $0.310^{* *}$ & 0.042 & $0.551^{* *}$ & 0.094 & $0.396^{*}$ & 0.195 \\
\hline ESP & $0.777^{* *}$ & 0.033 & -0.045 & 0.358 & 0.105 & 0.060 \\
\hline FIN & $0.734^{* *}$ & 0.058 & 0.577 & 0.998 & $0.271^{*}$ & 0.104 \\
\hline FRA & $0.831^{* *}$ & 0.034 & -0.158 & 0.085 & 0.100 & 0.068 \\
\hline GBR & $0.663^{* *}$ & 0.046 & $0.188^{* *}$ & 0.045 & $0.439^{* *}$ & 0.077 \\
\hline GRC & $0.743^{* *}$ & 0.101 & 0.140 & 0.070 & $0.238^{*}$ & 0.095 \\
\hline GTM & $0.813^{* *}$ & 0.242 & 1.133 & 0.750 & 0.471 & 0.507 \\
\hline HKG & $0.791^{* *}$ & 0.093 & $-0.681^{*}$ & 0.260 & 0.193 & 0.241 \\
\hline HUN & $0.798^{* *}$ & 0.106 & 0.163 & 0.157 & 0.298 & 0.196 \\
\hline IDN & 0.063 & 0.074 & 0.271 & 0.195 & $0.124^{* *}$ & 0.029 \\
\hline IND & $0.886^{* *}$ & 0.074 & 0.293 & 0.232 & $0.344^{*}$ & 0.163 \\
\hline IRL & 0.261 & 0.407 & 0.585 & 1.324 & 0.970 & 1.049 \\
\hline ISR & $0.726^{*}$ & 0.305 & -0.228 & 0.502 & -0.035 & 0.224 \\
\hline ITA & $0.811^{* *}$ & 0.025 & $-0.151^{* *}$ & 0.050 & $0.217^{* *}$ & 0.029 \\
\hline JPN & $0.407^{* *}$ & 0.050 & $0.131^{*}$ & 0.056 & $0.547^{* *}$ & 0.088 \\
\hline KOR & $0.668^{* *}$ & 0.069 & $0.256^{*}$ & 0.114 & $0.502^{* *}$ & 0.150 \\
\hline LKA & $0.632^{* *}$ & 0.086 & $0.518^{* *}$ & 0.188 & $0.461^{* *}$ & 0.133 \\
\hline MAR & $0.453^{* *}$ & 0.099 & $0.354^{*}$ & 0.165 & $0.700^{* *}$ & 0.126 \\
\hline MEX & 0.414 & 0.217 & 0.055 & 0.215 & 0.714 & 0.884 \\
\hline NLD & $0.727^{* *}$ & 0.053 & $-0.753^{*}$ & 0.326 & $0.413^{* *}$ & 0.133 \\
\hline NOR & $0.704^{* *}$ & 0.110 & 0.193 & 0.176 & $0.969^{*}$ & 0.421 \\
\hline NZL & $0.590^{* *}$ & 0.045 & $0.220^{* *}$ & 0.069 & $0.368^{*}$ & 0.162 \\
\hline PAK & $0.734^{* *}$ & 0.057 & $0.906^{* *}$ & 0.157 & $0.843^{* *}$ & 0.221 \\
\hline PER & $0.668^{* *}$ & 0.120 & -0.122 & 0.065 & $0.637^{* *}$ & 0.232 \\
\hline PHL & $0.946^{* *}$ & 0.306 & $0.314^{*}$ & 0.127 & -0.730 & 2.051 \\
\hline POL & $0.476^{* *}$ & 0.041 & -0.001 & 0.134 & $0.408^{* *}$ & 0.084 \\
\hline PRT & $0.512^{* *}$ & 0.068 & 0.268 & 0.415 & $0.260^{*}$ & 0.118 \\
\hline RUS & $0.852^{* *}$ & 0.099 & $0.964^{* *}$ & 0.315 & 0.335 & 0.248 \\
\hline SAU & 0.210 & 0.112 & $-0.784^{* *}$ & 0.212 & -0.811 & 1.033 \\
\hline SGP & $1.167^{* *}$ & 0.151 & -0.249 & 0.249 & -0.617 & 0.347 \\
\hline SWE & $0.618^{* *}$ & 0.057 & 0.781 & 0.470 & $0.539^{* *}$ & 0.104 \\
\hline THA & $0.500^{* *}$ & 0.095 & 0.567 & 0.451 & $0.723^{* *}$ & 0.241 \\
\hline TUN & $0.585^{* *}$ & 0.140 & 1.189 & 1.041 & 0.260 & 0.321 \\
\hline TUR & $0.542^{* *}$ & 0.044 & $0.258^{* *}$ & 0.046 & $0.508^{* *}$ & 0.068 \\
\hline URY & $0.793^{* *}$ & 0.106 & $0.182^{* *}$ & 0.039 & -0.283 & 0.312 \\
\hline USA & $0.848^{* *}$ & 0.058 & 0.128 & 0.071 & $-0.758^{* *}$ & 0.138 \\
\hline ZAF & $0.364^{* *}$ & 0.052 & $0.942 *$ & 0.355 & $0.126^{* *}$ & 0.019 \\
\hline
\end{tabular}

Note: ER is the estimated coefficient of the exchange rate, Inflation - Exp is inflation in the exporting country and Inflation - Imp is inflation in the importing country. 
Table 12: Estimates of exchange rate elasticities for import prices with inflation as control variable

\begin{tabular}{|c|c|c|c|c|c|c|}
\hline & \multicolumn{4}{|c|}{ Import Prices } & \multirow[b]{2}{*}{ Inflation - Imp. } & \multirow[b]{2}{*}{$(\mathrm{SE})$} \\
\hline & ER & (SE) & Inflation - Exp. & $(\mathrm{SE})$ & & \\
\hline ARG & $0.854^{* *}$ & 0.062 & $0.166^{* *}$ & 0.045 & $0.000^{* *}$ & 0.000 \\
\hline AUS & $0.706^{* *}$ & 0.089 & 0.243 & 0.334 & -0.241 & 0.124 \\
\hline AUT & $0.401^{* *}$ & 0.054 & 0.023 & 0.130 & $0.120^{*}$ & 0.057 \\
\hline BEL & $0.357^{* *}$ & 0.099 & 0.541 & 0.581 & 0.126 & 0.122 \\
\hline BRA & $0.537^{* *}$ & 0.059 & 0.384 & 0.250 & 0.123 & 0.062 \\
\hline CAN & $0.419^{* *}$ & 0.068 & $0.562^{*}$ & 0.264 & $-0.403^{* *}$ & 0.088 \\
\hline $\mathrm{CHE}$ & $0.381^{* *}$ & 0.082 & 0.437 & 0.296 & -0.244 & 0.152 \\
\hline CHL & $0.339^{*}$ & 0.152 & -0.758 & 0.991 & $0.000^{* *}$ & 0.000 \\
\hline $\mathrm{CHN}$ & $0.471^{* *}$ & 0.077 & 0.256 & 0.234 & $0.000^{* *}$ & 0.000 \\
\hline COL & $0.533^{* *}$ & 0.075 & -0.213 & 0.269 & $0.708^{* *}$ & 0.127 \\
\hline CRI & $0.568^{* *}$ & 0.208 & -0.036 & 0.424 & -0.328 & 0.800 \\
\hline CZE & $0.606^{* *}$ & 0.057 & $0.634^{* *}$ & 0.205 & -0.006 & 0.217 \\
\hline DEU & $0.439^{* *}$ & 0.042 & $0.316^{* *}$ & 0.111 & $0.309^{* *}$ & 0.067 \\
\hline DNK & $0.423^{* *}$ & 0.074 & $0.430^{* *}$ & 0.108 & 0.849 & 0.851 \\
\hline EGY & $0.590^{* *}$ & 0.069 & $0.709^{* *}$ & 0.150 & $0.607^{* *}$ & 0.203 \\
\hline ESP & $0.404^{* *}$ & 0.039 & $0.258^{* *}$ & 0.088 & 0.149 & 0.104 \\
\hline FIN & $0.623^{* *}$ & 0.093 & $0.552^{*}$ & 0.220 & $0.166^{* *}$ & 0.056 \\
\hline FRA & $0.505^{* *}$ & 0.056 & $0.320^{* *}$ & 0.109 & 0.549 & 1.258 \\
\hline GBR & $0.497^{* *}$ & 0.052 & $0.407^{* *}$ & 0.111 & $0.126^{*}$ & 0.053 \\
\hline GRC & $0.737^{* *}$ & 0.178 & 0.449 & 0.359 & 0.160 & 0.094 \\
\hline GTM & $0.273^{* *}$ & 0.093 & $0.622^{*}$ & 0.274 & 0.542 & 0.567 \\
\hline HKG & $0.702^{* *}$ & 0.135 & -1.164 & 1.712 & -0.525 & 0.321 \\
\hline HUN & $0.776^{* *}$ & 0.081 & $0.651^{*}$ & 0.261 & $0.406^{* *}$ & 0.128 \\
\hline IDN & $0.647^{* *}$ & 0.057 & 0.515 & 0.510 & 0.485 & 0.262 \\
\hline IND & $0.674^{* *}$ & 0.193 & 0.189 & 0.108 & -0.225 & 0.124 \\
\hline IRL & $0.537^{* *}$ & 0.139 & 0.573 & 0.392 & 0.479 & 0.465 \\
\hline ISR & $0.921^{* *}$ & 0.089 & $0.795^{* *}$ & 0.178 & 0.687 & 0.377 \\
\hline ITA & $0.520^{* *}$ & 0.053 & $0.391^{* *}$ & 0.106 & 0.082 & 0.809 \\
\hline JPN & $0.718^{* *}$ & 0.067 & $0.868^{* *}$ & 0.207 & 0.237 & 0.160 \\
\hline KOR & $0.548^{* *}$ & 0.097 & $0.427^{* *}$ & 0.123 & $0.496^{* *}$ & 0.083 \\
\hline LKA & 0.118 & 0.110 & -0.872 & 0.720 & $1.123^{* *}$ & 0.334 \\
\hline MAR & $0.742^{* *}$ & 0.183 & $0.784^{* *}$ & 0.221 & 0.193* & 0.089 \\
\hline MEX & 0.087 & 0.113 & $0.201^{* *}$ & 0.059 & $-0.146^{* *}$ & 0.017 \\
\hline NLD & $0.583^{* *}$ & 0.089 & $0.639^{*}$ & 0.251 & -0.203 & 0.736 \\
\hline NOR & $0.404^{* *}$ & 0.063 & $0.425^{* *}$ & 0.155 & 0.289 & 0.550 \\
\hline NZL & $0.569^{* *}$ & 0.108 & $0.147^{*}$ & 0.065 & 0.146 & 0.261 \\
\hline PAK & 0.213 & 0.121 & $0.511^{*}$ & 0.249 & $0.140^{* *}$ & 0.025 \\
\hline PER & $0.410^{* *}$ & 0.119 & 0.090 & 0.297 & $0.145^{* *}$ & 0.022 \\
\hline PHL & $0.522^{* *}$ & 0.139 & 0.533 & 0.521 & 1.084 & 0.696 \\
\hline POL & $0.551^{* *}$ & 0.032 & $0.662^{* *}$ & 0.226 & -0.038 & 0.081 \\
\hline PRT & $0.551^{* *}$ & 0.085 & 0.223 & 0.230 & 0.157 & 0.094 \\
\hline RUS & $0.711^{* *}$ & 0.027 & $0.317^{* *}$ & 0.061 & $0.817^{* *}$ & 0.051 \\
\hline SAU & 0.099 & 0.215 & -0.401 & 0.428 & $0.188^{* *}$ & 0.036 \\
\hline SGP & $0.375^{* *}$ & 0.100 & $0.817^{*}$ & 0.349 & $0.209^{*}$ & 0.099 \\
\hline SWE & $0.564^{* *}$ & 0.081 & $0.435^{* *}$ & 0.114 & 0.269 & 0.450 \\
\hline THA & $0.257^{* *}$ & 0.087 & $0.728^{*}$ & 0.277 & $0.174^{*}$ & 0.070 \\
\hline TUN & $0.596^{* *}$ & 0.164 & $0.600^{*}$ & 0.265 & $0.219^{*}$ & 0.085 \\
\hline TUR & $0.715^{* *}$ & 0.044 & $0.628^{* *}$ & 0.101 & $0.252^{* *}$ & 0.043 \\
\hline URY & $0.431^{* *}$ & 0.070 & -0.491 & 0.543 & $0.370^{* *}$ & 0.059 \\
\hline USA & $0.228^{* *}$ & 0.055 & 0.093 & 0.110 & 0.350 & 0.231 \\
\hline ZAF & $0.430^{* *}$ & 0.059 & 0.398 & 0.229 & $0.280^{* *}$ & 0.037 \\
\hline
\end{tabular}

Note: ER is the estimated coefficient of the exchange rate, Inflation - Exp is inflation in the exporting country and Inflation - Imp is inflation in the importing country. 
Table 13: Estimates of exchange rate elasticities for export quantities with inflation as control variable

\begin{tabular}{|c|c|c|c|c|c|c|c|c|}
\hline & \multicolumn{8}{|c|}{ Export Quantities } \\
\hline & ER & (SE) & GDP & $(\mathrm{SE})$ & Inflation - Exp. & (SE) & Inflation - Imp. & $(\mathrm{SE})$ \\
\hline ARG & 0.149 & 0.131 & 1.630 & 1.464 & $0.000^{* *}$ & 0.000 & -0.178 & 0.111 \\
\hline AUS & $0.903^{* *}$ & 0.240 & 1.381 & 0.686 & -0.696 & 4.137 & 0.130 & 0.109 \\
\hline AUT & $0.711^{* *}$ & 0.133 & $1.474^{* *}$ & 0.280 & $0.261^{*}$ & 0.098 & $0.767^{* *}$ & 0.175 \\
\hline BEL & $0.776^{* *}$ & 0.128 & $1.296^{* *}$ & 0.116 & $0.205^{*}$ & 0.077 & $0.996^{* *}$ & 0.143 \\
\hline BRA & $0.250^{* *}$ & 0.062 & $1.802^{* *}$ & 0.275 & $0.174^{* *}$ & 0.025 & $0.775^{* *}$ & 0.190 \\
\hline CAN & 0.321 & 0.170 & $1.635^{* *}$ & 0.359 & 0.167 & 0.241 & $1.194^{*}$ & 0.472 \\
\hline CHE & $0.906^{* *}$ & 0.105 & $1.424^{* *}$ & 0.308 & $1.051^{* *}$ & 0.132 & $0.212^{* *}$ & 0.044 \\
\hline CHL & $0.397^{* *}$ & 0.114 & $1.678^{* *}$ & 0.403 & $-0.194^{*}$ & 0.074 & $0.171^{* *}$ & 0.041 \\
\hline $\mathrm{CHN}$ & $0.695^{* *}$ & 0.056 & $1.132^{* *}$ & 0.155 & $0.000^{* *}$ & 0.000 & $0.817^{* *}$ & 0.146 \\
\hline COL & 0.385 & 0.204 & $1.202^{*}$ & 0.529 & $0.127^{* *}$ & 0.037 & $-0.221^{* *}$ & 0.077 \\
\hline CRI & $0.748^{* *}$ & 0.130 & 1.247 & 0.698 & 0.843 & 2.668 & $0.257^{*}$ & 0.113 \\
\hline $\mathrm{CZE}$ & $0.611^{* *}$ & 0.092 & $1.062^{* *}$ & 0.168 & $0.282^{* *}$ & 0.031 & $0.957^{* *}$ & 0.149 \\
\hline $\mathrm{DEU}$ & $0.511^{* *}$ & 0.054 & $0.699^{* *}$ & 0.051 & 0.208 & 0.598 & $0.634^{* *}$ & 0.047 \\
\hline DNK & $0.467^{* *}$ & 0.088 & $0.550^{* *}$ & 0.165 & 0.289 & 0.954 & $0.805^{* *}$ & 0.150 \\
\hline EGY & $0.284^{*}$ & 0.136 & 0.515 & 0.359 & -0.155 & 0.097 & 0.446 & 0.391 \\
\hline ESP & $0.703^{* *}$ & 0.079 & $0.811^{* *}$ & 0.157 & $0.251^{* *}$ & 0.063 & $0.123^{* *}$ & 0.010 \\
\hline FIN & $0.749^{* *}$ & 0.107 & $0.978^{* *}$ & 0.182 & $-0.215^{*}$ & 0.106 & $1.083^{* *}$ & 0.152 \\
\hline FRA & $0.568^{* *}$ & 0.076 & $0.397^{*}$ & 0.159 & $0.558^{* *}$ & 0.074 & $0.856^{* *}$ & 0.106 \\
\hline GBR & $0.464^{* *}$ & 0.079 & $0.620^{* *}$ & 0.122 & 0.123 & 0.063 & $0.645^{* *}$ & 0.090 \\
\hline GRC & $0.713^{* *}$ & 0.201 & $0.814^{* *}$ & 0.268 & $0.208^{*}$ & 0.084 & $0.630^{* *}$ & 0.219 \\
\hline GTM & 0.553 & 0.291 & $0.169^{* *}$ & 0.059 & 0.749 & 0.981 & 0.292 & 0.436 \\
\hline HKG & 0.173 & 0.295 & 0.568 & 0.309 & 0.321 & 0.265 & -0.376 & 0.601 \\
\hline HUN & $0.595^{* *}$ & 0.173 & $1.193^{* *}$ & 0.424 & $0.369^{* *}$ & 0.047 & 0.320 & 0.207 \\
\hline IDN & 0.190 & 0.101 & $0.708^{* *}$ & 0.223 & -0.431 & 0.226 & 0.463 & 0.348 \\
\hline IND & $0.468^{* *}$ & 0.111 & $0.908^{* *}$ & 0.127 & $-0.139 * *$ & 0.029 & $0.629^{*}$ & 0.285 \\
\hline IRL & 0.069 & 0.282 & 1.066 & 0.776 & -0.131 & 0.147 & -0.081 & 0.834 \\
\hline ISR & 0.348 & 0.266 & $1.386^{* *}$ & 0.451 & $0.178^{*}$ & 0.080 & $0.840^{* *}$ & 0.293 \\
\hline ITA & $0.520^{* *}$ & 0.033 & $0.852^{* *}$ & 0.076 & $0.664^{* *}$ & 0.044 & $0.518^{* *}$ & 0.042 \\
\hline JPN & 0.179 & 0.099 & $1.053^{* *}$ & 0.146 & $0.395^{* *}$ & 0.063 & -0.095 & 0.156 \\
\hline KOR & $0.531^{* *}$ & 0.115 & $1.059^{* *}$ & 0.278 & $0.760^{* *}$ & 0.192 & 0.230 & 0.313 \\
\hline LKA & 0.261 & 0.149 & $1.091^{* *}$ & 0.381 & -0.370 & 0.256 & 0.456 & 0.513 \\
\hline MAR & $0.293^{*}$ & 0.143 & $0.888^{* *}$ & 0.273 & 0.144 & 0.123 & 0.303 & 0.215 \\
\hline MEX & 0.373 & 0.279 & $1.919^{* *}$ & 0.558 & $0.135^{* *}$ & 0.032 & 1.099 & 1.227 \\
\hline NLD & $0.729^{* *}$ & 0.085 & $0.970^{* *}$ & 0.110 & 0.863 & 0.529 & $0.946^{* *}$ & 0.115 \\
\hline NOR & $0.458^{*}$ & 0.202 & $0.506^{*}$ & 0.239 & $0.204^{* *}$ & 0.075 & 0.633 & 0.426 \\
\hline NZL & $0.239^{* *}$ & 0.053 & $0.731^{* *}$ & 0.176 & -0.117 & 0.894 & 0.485 & 0.289 \\
\hline PAK & $0.852^{* *}$ & 0.136 & $1.480^{* *}$ & 0.261 & $-1.174^{* *}$ & 0.311 & 0.678 & 0.377 \\
\hline PER & 0.199 & 0.101 & 1.280 & 0.653 & $0.202^{* *}$ & 0.064 & 0.087 & 0.325 \\
\hline PHL & 0.661 & 0.507 & 0.897 & 2.448 & 0.160 & 0.259 & 1.199 & 1.734 \\
\hline POL & $0.254^{*}$ & 0.095 & $1.917^{* *}$ & 0.268 & $0.197^{* *}$ & 0.023 & 0.120 & 0.215 \\
\hline PRT & $0.452^{* *}$ & 0.122 & 0.203 & 0.173 & $0.561^{* *}$ & 0.091 & $0.642^{* *}$ & 0.161 \\
\hline RUS & $0.305^{* *}$ & 0.051 & $0.723^{* *}$ & 0.231 & 0.282 & 0.166 & -0.089 & 0.257 \\
\hline SAU & $0.730^{* *}$ & 0.150 & $1.278^{* *}$ & 0.237 & 0.678 & 0.436 & $0.313^{*}$ & 0.148 \\
\hline SGP & $0.637^{* *}$ & 0.187 & 0.679 & 0.563 & 0.773 & 2.635 & $0.150^{* *}$ & 0.021 \\
\hline SWE & $0.328^{* *}$ & 0.096 & $0.867^{* *}$ & 0.116 & -0.539 & 0.908 & $0.546^{* *}$ & 0.187 \\
\hline THA & $0.388^{* *}$ & 0.125 & $0.759^{* *}$ & 0.260 & $0.223^{* *}$ & 0.057 & $0.498^{*}$ & 0.222 \\
\hline TUN & 0.013 & 0.166 & 1.472 & 0.771 & -0.382 & 0.253 & 0.707 & 0.472 \\
\hline TUR & $0.305^{* *}$ & 0.065 & $1.209^{* *}$ & 0.130 & $0.286^{* *}$ & 0.082 & 0.041 & 0.135 \\
\hline URY & $0.661^{* *}$ & 0.185 & 1.333 & 0.716 & 0.020 & 0.636 & $0.156^{* *}$ & 0.053 \\
\hline USA & $0.389^{* *}$ & 0.070 & 0.009 & 0.109 & $0.250^{* *}$ & 0.067 & $0.131^{* *}$ & 0.017 \\
\hline $\mathrm{ZAF}$ & $0.426^{* *}$ & 0.121 & $1.326^{*}$ & 0.553 & -0.973 & 1.056 & $0.743^{*}$ & 0.331 \\
\hline
\end{tabular}

Note: ER is the estimated coefficient of the exchange rate, GDP is GDP of the importing country, Inflation - Exp is inflation in the exporting country and Inflation - Imp is inflation in the importing country. 
Table 14: Estimates of exchange rate elasticities for import quantities with inflation as control variable

\begin{tabular}{|c|c|c|c|c|c|c|c|c|}
\hline & \multicolumn{4}{|c|}{ Import Quantities } & \multirow[b]{2}{*}{ Inflation - Exp. } & \multirow[b]{2}{*}{ (SE) } & \multirow[b]{2}{*}{ Inflation - Imp. } & \multirow[b]{2}{*}{$(\mathrm{SE})$} \\
\hline & $\mathrm{ER}$ & (SE) & GDP & (SE) & & & & \\
\hline ARG & $-0.492^{* *}$ & 0.104 & $1.189^{* *}$ & 0.150 & 0.902 & 0.521 & $0.000^{* *}$ & 0.000 \\
\hline AUS & -0.236 & 0.123 & $1.960^{*}$ & 0.741 & $0.173^{*}$ & 0.064 & $0.548^{* *}$ & 0.158 \\
\hline AUT & -0.143 & 0.089 & $1.272^{* *}$ & 0.258 & $0.150^{* *}$ & 0.030 & 0.611 & 0.647 \\
\hline BEL & -0.135 & 0.123 & $0.960^{*}$ & 0.362 & 0.639 & 0.495 & 0.915 & 0.922 \\
\hline BRA & $-0.204^{* *}$ & 0.043 & 0.023 & 0.510 & $1.003^{* *}$ & 0.249 & -0.095 & 0.404 \\
\hline CAN & $-0.325^{* *}$ & 0.091 & $1.100^{* *}$ & 0.369 & 0.259 & 0.282 & $0.316^{* *}$ & 0.098 \\
\hline CHE & -0.037 & 0.218 & 0.224 & 0.907 & $0.249^{* *}$ & 0.087 & $0.646^{* *}$ & 0.186 \\
\hline CHL & -0.332 & 0.178 & $1.116^{* *}$ & 0.326 & $0.254^{* *}$ & 0.086 & $0.000^{* *}$ & 0.000 \\
\hline $\mathrm{CHN}$ & -0.040 & 0.104 & 0.493 & 0.474 & 0.420 & 0.248 & $0.000^{* *}$ & 0.000 \\
\hline $\mathrm{COL}$ & $-0.584^{* *}$ & 0.133 & 1.295 & 1.115 & -0.179 & 0.392 & $0.595^{* *}$ & 0.046 \\
\hline CRI & $-0.966^{*}$ & 0.361 & 1.798 & 1.078 & 0.551 & 1.361 & $0.518^{* *}$ & 0.101 \\
\hline CZE & $-0.286^{* *}$ & 0.079 & $1.612^{* *}$ & 0.245 & 0.084 & 0.224 & $0.285^{* *}$ & 0.022 \\
\hline DEU & -0.007 & 0.058 & $1.137^{* *}$ & 0.180 & $0.454^{* *}$ & 0.113 & $-0.170^{*}$ & 0.081 \\
\hline DNK & $-0.247^{*}$ & 0.121 & $1.069^{* *}$ & 0.224 & $0.667^{* *}$ & 0.201 & 0.817 & 0.935 \\
\hline EGY & $-0.385^{*}$ & 0.182 & $0.992^{* *}$ & 0.336 & 0.202 & 0.479 & -0.097 & 0.427 \\
\hline ESP & $-0.138^{*}$ & 0.053 & $1.646^{* *}$ & 0.219 & 0.159 & 0.201 & $0.364^{* *}$ & 0.069 \\
\hline FIN & $-0.197^{*}$ & 0.092 & $1.542^{* *}$ & 0.250 & $1.187^{* *}$ & 0.196 & $-0.253^{* *}$ & 0.060 \\
\hline FRA & $-0.138^{*}$ & 0.057 & $1.902^{* *}$ & 0.142 & $0.448^{* *}$ & 0.125 & $0.443^{* *}$ & 0.089 \\
\hline GBR & -0.036 & 0.111 & $1.268^{* *}$ & 0.275 & $0.696^{* *}$ & 0.174 & $-0.156^{*}$ & 0.068 \\
\hline GRC & $-0.737^{*}$ & 0.337 & $1.635^{* *}$ & 0.385 & -0.337 & 0.499 & $0.393^{* *}$ & 0.100 \\
\hline GTM & -0.260 & 0.178 & 1.782 & 1.029 & 0.273 & 0.373 & $0.124^{*}$ & 0.057 \\
\hline HKG & -0.018 & 0.217 & 0.473 & 0.953 & 0.201 & 0.146 & $0.665^{*}$ & 0.304 \\
\hline HUN & $-0.270^{* *}$ & 0.082 & $1.279^{* *}$ & 0.271 & 0.049 & 0.257 & $0.296^{* *}$ & 0.028 \\
\hline IDN & $-0.284^{*}$ & 0.117 & 0.242 & 0.233 & $0.238^{* *}$ & 0.068 & $-1.011^{* *}$ & 0.293 \\
\hline IND & $-0.642^{*}$ & 0.245 & 1.772 & 2.256 & -0.594 & 0.638 & 0.229 & 0.160 \\
\hline IRL & -0.472 & 0.261 & $1.786^{* *}$ & 0.273 & 0.816 & 1.085 & -0.057 & 0.422 \\
\hline ISR & $-0.440^{* *}$ & 0.141 & 1.245 & 1.076 & $0.798^{*}$ & 0.349 & -0.486 & 0.375 \\
\hline ITA & $-0.303^{* *}$ & 0.053 & $1.216^{* *}$ & 0.150 & -0.015 & 0.125 & $0.211^{* *}$ & 0.076 \\
\hline JPN & -0.133 & 0.099 & $1.564^{* *}$ & 0.314 & 0.054 & 0.139 & 0.243 & 0.123 \\
\hline KOR & -0.096 & 0.066 & $1.315^{* *}$ & 0.412 & 0.327 & 0.253 & $0.302^{* *}$ & 0.074 \\
\hline LKA & -0.162 & 0.206 & 0.283 & 0.501 & 0.203 & 0.118 & -0.151 & 0.566 \\
\hline MAR & $-0.628^{*}$ & 0.245 & $0.764^{* *}$ & 0.165 & -0.108 & 0.318 & $0.649^{* *}$ & 0.139 \\
\hline MEX & $-1.229^{* *}$ & 0.144 & $1.552^{*}$ & 0.745 & 0.137 & 0.076 & $0.341^{* *}$ & 0.021 \\
\hline NLD & $-0.257^{*}$ & 0.119 & $1.655^{* *}$ & 0.233 & 0.387 & 0.257 & 0.283 & 0.823 \\
\hline NOR & -0.007 & 0.154 & $0.319^{*}$ & 0.147 & 0.438 & 0.501 & $-0.352^{* *}$ & 0.125 \\
\hline NZL & $-0.364^{*}$ & 0.175 & 1.512 & 1.355 & 0.149 & 0.082 & -0.128 & 0.236 \\
\hline PAK & -0.216 & 0.219 & 1.811 & 1.508 & -0.470 & 0.649 & $-0.239^{* *}$ & 0.073 \\
\hline PER & $-0.688^{* *}$ & 0.214 & $1.549^{* *}$ & 0.262 & -0.150 & 0.306 & $0.197^{* *}$ & 0.036 \\
\hline PHL & -0.113 & 0.185 & 0.366 & 0.375 & 0.631 & 0.547 & -0.660 & 1.136 \\
\hline POL & $-0.347^{* *}$ & 0.062 & $0.912^{* *}$ & 0.268 & 0.034 & 0.252 & $0.221^{* *}$ & 0.013 \\
\hline PRT & $-0.247^{* *}$ & 0.083 & $1.334^{* *}$ & 0.231 & $0.485^{*}$ & 0.182 & $0.218^{* *}$ & 0.065 \\
\hline RUS & $-0.624^{* *}$ & 0.059 & $0.889^{* *}$ & 0.144 & $0.589^{* *}$ & 0.142 & $0.531^{* *}$ & 0.118 \\
\hline SAU & -0.183 & 0.261 & 0.363 & 0.225 & $1.127^{*}$ & 0.447 & $-0.143^{* *}$ & 0.041 \\
\hline SGP & -0.104 & 0.147 & 0.136 & 0.280 & 0.167 & 0.366 & -0.229 & 0.126 \\
\hline SWE & -0.129 & 0.103 & $1.882^{* *}$ & 0.254 & $0.910^{* *}$ & 0.148 & -0.732 & 0.473 \\
\hline THA & -0.226 & 0.177 & $1.619^{* *}$ & 0.252 & $1.118^{* *}$ & 0.355 & 0.490 & 0.821 \\
\hline TUN & $-0.412^{* *}$ & 0.136 & 0.310 & 0.173 & -0.084 & 0.355 & -0.841 & 0.880 \\
\hline TUR & $-0.683^{* *}$ & 0.109 & $1.545^{* *}$ & 0.155 & $-0.876^{* *}$ & 0.210 & $1.178^{* *}$ & 0.111 \\
\hline URY & $-0.278^{*}$ & 0.118 & $1.365^{*}$ & 0.640 & 0.161 & 0.126 & $-0.165^{* *}$ & 0.057 \\
\hline USA & -0.069 & 0.056 & $1.777^{* *}$ & 0.497 & 0.094 & 0.111 & -0.028 & 1.000 \\
\hline $\mathrm{ZAF}$ & -0.050 & 0.081 & 1.446 & 1.284 & $1.186^{* *}$ & 0.284 & $-0.318^{* *}$ & 0.062 \\
\hline
\end{tabular}

Note: ER is the estimated coefficient of the exchange rate, GDP is GDP of the importing country, Inflation - Exp is inflation in the exporting country and Inflation - Imp is inflation in the importing country. 
Table 15: Estimates of long-run exchange rate elasticities for export prices

\begin{tabular}{|c|c|c|c|c|c|c|}
\hline & ER & $(\mathrm{SE})$ & $\begin{array}{l}\text { Export } \\
\text { LAG.ER }\end{array}$ & $\begin{array}{c}\text { Prices } \\
(\mathrm{SE})\end{array}$ & LAG.2.ER & (SE) \\
\hline ARG & 0.073 & 0.085 & $-0.353^{* *}$ & 096 & -0.102 & 0.055 \\
\hline US & $0.652^{* *}$ & 195 & 0.304 & 256 & -0.465 & 0.380 \\
\hline UT & $055^{\circ}$ & 106 & -0.093 & 10 & .113 & 106 \\
\hline BEL & 839 & 0.079 & -0.1 & & .073 & 057 \\
\hline RA & 537 & 0.0 & 101 & & -0.037 & 048 \\
\hline CAN & 0.511 & 0.128 & 0.30 & & -0.068 & 093 \\
\hline CHE & 0.865 & 0.076 & 0.19 & & -0.63 & 191 \\
\hline CHL & 1.17 & $0.1 \xi$ & $0.0^{\prime}$ & & 0.2 & 100 \\
\hline $\mathrm{CHN}$ & 0.89 & 0.042 & -0.20 & & & 049 \\
\hline $\mathrm{COL}$ & 0.68 & 0.0 & 0.0 & & & 163 \\
\hline CRI & -0.2 & 0. & & & & 190 \\
\hline CZE & 0.677 & 0.04 & 0.10 & & & 036 \\
\hline DEU & 0.89 & 0.025 & -0.07 & & & 032 \\
\hline DNK & 0.70 & 0.082 & -0.0 & & & 049 \\
\hline EGY & 0.502 & 0.071 & -0.29 & 99 & & 071 \\
\hline ESP & 0.85 & 0.03 & -0.0 & & & 034 \\
\hline FIN & 0.80 & 0.04 & & & & 035 \\
\hline FRA & 0.91 & 0.03 & -0.1 & & & 068 \\
\hline GBR & 0.72 & 0.06 & 0.0 & & -0.1 & 0.044 \\
\hline GRC & 0.76 & 0.13 & 0.20 & 0.07 & -0.1 & 0.058 \\
\hline GTM & 1.134 & 0.23 & -0.3 & 0.214 & 0.3 & 0.164 \\
\hline HKG & 0.864 & 0.094 & -0.1 & 0.128 & $0.222^{*}$ & 0.105 \\
\hline HUN & $1.021^{* *}$ & 0.16 & 0.10 & .19 & 0.1 & 0.128 \\
\hline IDN & 0.007 & 0.06 & 0.25 & 0.0 & 0.0 & 0.049 \\
\hline IND & $0.937^{* *}$ & 0.074 & 0.16 & 0.062 & -0.12 & 0.055 \\
\hline RL & 0.418 & 0.42 & -0.410 & 0.3 & 0.3 & 0.377 \\
\hline ISR & 0.699 & 0.394 & 0.562 & .3 & -0.3 & 0.287 \\
\hline ITA & $0.904^{* *}$ & 0.022 & -0.0 & .027 & 0.0 & 0.018 \\
\hline JPN & $0.505^{*}$ & 0.053 & -0.236 & 0.0 & 0.10 & 0.026 \\
\hline OR & $.513^{*}$ & 0.06 & 0.21 & & 0.0 & 0.059 \\
\hline LKA & $0.675^{\circ}$ & 0.10 & -0.0 & & -0 . & 0.0 \\
\hline MAR & 0.68 & 0.1 & -0.4 & & & 52 \\
\hline MEX & 0.22 & 0.2 & 0.1 & & & \\
\hline NLD & $0.855^{*}$ & 0.05 & -0.20 & & .1 & 0.0 \\
\hline NOR & * & 0.14 & $-0.0 \varepsilon$ & & & 0.236 \\
\hline NZL & $550^{*}$ & 0.04 & 017 & & -0.0 & 45 \\
\hline PAK & * & 0.0 & 0.35 & & -0 & 99 \\
\hline PER & 815 & 0.12 & -0.1 & & 0.2 & 0.184 \\
\hline PHL & $801 *$ & 0.29 & -0.5 & 0.646 & 0.83 & 0.310 \\
\hline POL & $524^{* *}$ & 0.041 & $0.085^{*}$ & 0.039 & -0.0 & 0.025 \\
\hline PRT & $620 *$ & 0.062 & 0.01 & 0.075 & 019 & 0.060 \\
\hline RUS & $614^{* *}$ & 0.077 & $-0.403^{3}$ & 0.090 & $0.158^{* *}$ & 0.038 \\
\hline SAU & $636^{* *}$ & 0.220 & $-0.490^{* *}$ & 0.143 & $-0.197^{* *}$ & 0.054 \\
\hline SGP & $0.956^{* *}$ & 0.079 & -0.065 & 0.061 & -0.072 & 0.115 \\
\hline SWE & $0.773^{* *}$ & 0.063 & 0.056 & 0.072 & 0.043 & 0.074 \\
\hline THA & $0.480^{* *}$ & 0.095 & $0.357^{* *}$ & 0.117 & -0.154 & 0.097 \\
\hline TUN & $0.878^{* *}$ & 0.119 & $-0.310^{*}$ & 0.146 & 0.164 & 0.096 \\
\hline TUR & $417^{* *}$ & 0.035 & 0.014 & 0.028 & $-0.082^{* *}$ & 0.020 \\
\hline URY & $0.547^{* *}$ & 0.062 & $-0.262^{* *}$ & 0.042 & $0.135^{*}$ & 0.060 \\
\hline USA & $0.830^{* *}$ & 0.055 & $-0.173^{* *}$ & 0.046 & $0.164^{* *}$ & 0.059 \\
\hline ZAF & $0.345^{* *}$ & 0.066 & 0.103 & 0.081 & 0.088 & 0.061 \\
\hline
\end{tabular}

Note: ER is the estimated coefficient of the exchange rate. LAG and LAG2 are the 1- and the 2-period lag coefficients of the exchange rate. 
Table 16: Estimates of long-run exchange rate elasticities for import prices

\begin{tabular}{|c|c|c|c|c|c|c|}
\hline & ER & (SE) & $\begin{array}{l}\text { Impor } \\
\text { LAG.ER }\end{array}$ & $\begin{array}{c}\text { Prices } \\
\text { (SE) }\end{array}$ & LAG.2.ER & (SE) \\
\hline ARG & $0.671^{* *}$ & 0.056 & 0.185 & 0.092 & 0.182 & 0.156 \\
\hline AUS & $0.563^{* *}$ & 0.124 & $0.325^{* *}$ & .112 & $-0.280^{*}$ & 0.115 \\
\hline AUT & $0.494^{* *}$ & 0.056 & 0.115 & 0.079 & 0.023 & 0.069 \\
\hline BEL & $0.306^{* *}$ & 0.056 & -0.070 & 0.092 & -0.010 & 0.061 \\
\hline BRA & $0.588^{* *}$ & 0.053 & -0.165 & 0.033 & 0.069 & 0.035 \\
\hline CAN & $0.441^{* *}$ & 0.059 & -0.094 & 0.064 & $-0.229^{*}$ & 0.101 \\
\hline CHE & $0.262^{* *}$ & 0.066 & -0.233 & 0.131 & 0.155 & 0.098 \\
\hline CHL & 0.256 & 0.214 & -0.3 & 0.437 & -0.053 & 0.066 \\
\hline $\mathrm{CHN}$ & $0.381^{* *}$ & 0.047 & $0.184^{* *}$ & 0.058 & $-0.173^{*}$ & 0.077 \\
\hline COL & $0.847^{* *}$ & 0.081 & -0.165 & 0.099 & $-0.374^{* *}$ & 0.107 \\
\hline CRI & $0.713^{3}$ & 0.191 & 0.244 & 0.587 & 0.246 & 0.385 \\
\hline CZE & $0.462^{* *}$ & 0.072 & -0.121 & 0.114 & 0.071 & 0.072 \\
\hline DEU & $0.365^{* *}$ & 0.042 & 0.032 & 0.082 & $-0.137^{* *}$ & 0.042 \\
\hline DNK & $0.391^{\star}$ & 0.057 & 0.08 & 0.044 & -0.068 & 0.050 \\
\hline EGY & $0.409^{* *}$ & 0.077 & $0.239^{* *}$ & 0.071 & -0.214 & 0.110 \\
\hline ESP & $0.363^{* *}$ & 0.044 & 0.016 & 0.073 & $-0.061^{*}$ & 0.026 \\
\hline FIN & $0.547^{* *}$ & 0.075 & $-0.257^{*}$ & 0.117 & -0.012 & 0.042 \\
\hline FRA & $0.421^{* *}$ & 0.072 & 0.002 & 0.105 & $-0.072^{*}$ & 0.035 \\
\hline GBR & $0.439^{* *}$ & 0.043 & 0.043 & 0.054 & -0.032 & 0.044 \\
\hline GRC & $0.641^{* *}$ & 0.134 & 0.341 & 0.308 & -0.379 & 0.367 \\
\hline GTM & 0.129 & 0.153 & $0.465^{* *}$ & 0.136 & -0.273 & 0.184 \\
\hline HKG & $0.782^{* *}$ & 0.077 & -0.015 & 0.158 & -0.093 & 0.132 \\
\hline HUN & $0.725^{* *}$ & 0.103 & -0.247 & 0.146 & 0.100 & 0.056 \\
\hline IDN & $0.660^{* *}$ & 0.113 & -0.119 & 0.077 & -0.035 & 0.085 \\
\hline IND & $0.431^{*}$ & 0.177 & 0.243 & 0.433 & 0.196 & 0.155 \\
\hline IRL & $0.547^{* *}$ & 0.150 & 0.042 & 0.122 & 0.093 & 0.139 \\
\hline ISR & $0.867^{* *}$ & 0.105 & -0.189 & 0.124 & -0.159 & 0.109 \\
\hline ITA & $0.432^{* *}$ & 0.047 & -0.070 & 0.084 & -0.008 & 0.027 \\
\hline JPN & $0.957^{* *}$ & 0.061 & $0.251^{* *}$ & 0.057 & -0.130 & 0.065 \\
\hline KOR & $0.683^{* *}$ & 0.083 & $-0.215^{* *}$ & 0.072 & -0.022 & 0.068 \\
\hline LKA & 0.102 & 0.080 & 0.146 & 0.095 & $-0.210^{* *}$ & 0.076 \\
\hline MAR & $0.650^{* *}$ & 0.189 & -0.087 & 0.133 & 0.025 & 0.040 \\
\hline MEX & $0.507^{* *}$ & 0.097 & $-0.874^{* *}$ & 0.130 & $1.616^{* *}$ & 0.149 \\
\hline NLD & $0.469^{* *}$ & 0.096 & -0.116 & 0.086 & -0.051 & 0.067 \\
\hline NOR & $0.362^{* *}$ & 0.065 & -0.037 & 0.077 & 0.088 & 0.072 \\
\hline NZL & $0.588^{* *}$ & 0.082 & -0.043 & 0.098 & 0.009 & 0.093 \\
\hline PAK & $0.298^{* *}$ & 0.097 & 0.054 & 0.166 & 0.014 & 0.111 \\
\hline PER & $0.521^{* *}$ & 0.118 & 0.023 & 0.093 & -0.004 & 0.052 \\
\hline PHL & $0.528^{* *}$ & 0.126 & -0.076 & 0.159 & 0.048 & 0.109 \\
\hline POL & $0.443^{* *}$ & 0.051 & -0.166 & 0.114 & 0.078 & 0.060 \\
\hline PRT & $0.458^{* *}$ & 0.114 & -0.136 & 0.116 & 0.014 & 0.060 \\
\hline RUS & $0.842^{* *}$ & 0.027 & $-0.085^{* *}$ & 0.024 & $-0.062^{* *}$ & 0.021 \\
\hline SAU & 0.105 & 0.279 & 0.504 & 0.330 & -0.200 & 0.114 \\
\hline SGP & 0.121 & 0.085 & -0.043 & 0.063 & $-0.388^{* *}$ & 0.091 \\
\hline SWE & $0.476^{* *}$ & 0.082 & -0.181 & 0.091 & -0.119 & 0.074 \\
\hline THA & 0.188 & 0.134 & 0.066 & 0.129 & $-0.249^{*}$ & 0.115 \\
\hline TUN & $0.445^{* *}$ & 0.112 & -0.029 & 0.099 & 0.041 & 0.070 \\
\hline TUR & $0.832^{* *}$ & 0.032 & -0.033 & 0.035 & $0.125^{* *}$ & 0.039 \\
\hline URY & $0.206^{* *}$ & 0.074 & -0.034 & 0.098 & -0.175 & 0.100 \\
\hline USA & $0.316^{* *}$ & 0.036 & 0.020 & 0.043 & 0.023 & 0.070 \\
\hline ZAF & $0.498^{* *}$ & 0.071 & $0.283^{*}$ & 0.118 & -0.124 & 0.063 \\
\hline
\end{tabular}

Note: ER is the estimated coefficient of the exchange rate. LAG and LAG2 are the 1- and the 2-period lag coefficients of the exchange rate. 
Table 17: Estimates of long-run exchange rate elasticities for export quantities

\begin{tabular}{|c|c|c|c|c|c|c|c|c|}
\hline & \multicolumn{8}{|c|}{ Export Quantities } \\
\hline & ER & $(\mathrm{SE})$ & GDP & (SE) & LAG.ER & (SE) & LAG.2.ER & $(\mathrm{SE})$ \\
\hline ARG & 0.001 & 0.098 & 0.888 & 0.552 & $-0.470^{* *}$ & 0.136 & $-0.217^{* *}$ & 0.071 \\
\hline AUS & $0.876^{* *}$ & 0.173 & 0.969 & 0.635 & -0.076 & 0.203 & -0.281 & 0.309 \\
\hline AUT & $0.567^{* *}$ & 0.137 & $1.505^{* *}$ & 0.310 & -0.064 & 0.124 & -0.011 & 0.117 \\
\hline BEL & $0.583^{* *}$ & 0.124 & $1.213^{* *}$ & 0.158 & -0.071 & 0.079 & $-0.119^{*}$ & 0.058 \\
\hline BRA & $0.434^{* *}$ & 0.061 & $2.024^{* *}$ & 0.349 & $0.246^{* *}$ & 0.068 & $0.140^{*}$ & .055 \\
\hline CAN & 0.329 & 0.214 & $1.955^{* *}$ & 0.411 & 0.158 & 0.110 & 0.021 & 106 \\
\hline $\mathrm{CHE}$ & $0.810^{* *}$ & 0.119 & $1.683^{* *}$ & 0.371 & $0.406^{* *}$ & 0.105 & $-0.806^{* *}$ & 148 \\
\hline CHL & $0.722^{* *}$ & 0.099 & $1.675^{* *}$ & 0.472 & -0.052 & 0.151 & $0.298^{* *}$ & .097 \\
\hline $\mathrm{CHN}$ & $0.966^{* *}$ & 0.056 & $0.863^{* *}$ & 0.172 & 0.080 & 0.050 & -0.030 & 0.055 \\
\hline COL & 0.380 & 0.197 & $1.764^{* *}$ & 0.524 & -0.124 & 0.186 & -0 . & .241 \\
\hline CRI & $0.618^{*}$ & 0.275 & 1.116 & 0.638 & 1.064 & 0.742 & -0.193 & 0.928 \\
\hline $\mathrm{CZE}$ & $0.350^{* *}$ & 0.086 & $1.120^{* *}$ & 0.163 & $0.476^{* *}$ & 0.086 & $-0 .($ & 0.076 \\
\hline $\mathrm{DEU}$ & $0.542^{* *}$ & 0.056 & 0.731 & 0.049 & 0.018 & 0.028 & -0.058 & 0.035 \\
\hline DNK & $0.405^{* *}$ & 0.064 & $0.459^{* *}$ & 0.152 & 0.057 & 0.053 & -0.105 & 0.088 \\
\hline EGY & $0.526^{*}$ & 0.213 & 0.749 & 0.449 & -0.222 & 0.160 & 0.202 & 0.164 \\
\hline ESP & $0.652^{* *}$ & 0.070 & $0.714^{* *}$ & 0.115 & -0.006 & 0.076 & $-0.152^{*}$ & 0.066 \\
\hline FIN & $0.416^{* *}$ & 0.096 & $0.990^{* *}$ & 0.173 & $0.246^{* *}$ & 0.089 & $-0.304^{* *}$ & 0.077 \\
\hline FRA & $0.474^{* *}$ & 0.040 & $0.678^{*}$ & 0.120 & -0.004 & 0.092 & -0.159 & 0.105 \\
\hline GBR & $0.580^{* *}$ & 0.090 & $0.581^{* *}$ & 0.138 & $-0.165^{* *}$ & 0.058 & -0.028 & 0.053 \\
\hline GRC & $0.596^{* *}$ & 0.174 & $0.966^{* *}$ & 0.193 & -0.005 & 0.210 & -0.108 & 0.133 \\
\hline GTM & 0.813 & 0.432 & $0.215^{* *}$ & 0.053 & 0.343 & 0.243 & 0.350 & 0.237 \\
\hline HKG & $0.595^{*}$ & 0.247 & 0.410 & 0.317 & $-0.351^{*}$ & 0.136 & 0.267 & 0.344 \\
\hline HUN & $1.062^{* *}$ & 0.246 & $1.235^{* *}$ & 0.296 & 0.231 & 0.203 & $0.450^{*}$ & 0.195 \\
\hline IDN & $0.517^{* *}$ & 0.084 & $0.537^{*}$ & 0.257 & -0.126 & 0.071 & -0.105 & 0.065 \\
\hline IND & $0.448^{* *}$ & 0.077 & $0.991 * *$ & 0.136 & -0.016 & 0.086 & 0.108 & 0.098 \\
\hline IRL & 0.642 & 0.377 & 0.810 & 0.909 & -0.555 & 0.435 & 0.372 & 0.343 \\
\hline ISR & 0.556 & 0.307 & $1.242^{*}$ & 0.593 & $0.725^{* *}$ & 0.175 & -0.396 & 0.243 \\
\hline ITA & $0.664^{* *}$ & 0.041 & $0.769^{* *}$ & 0.082 & $-0.099 *$ & 0.039 & $-0.097^{* *}$ & 0.026 \\
\hline JPN & $0.432^{* *}$ & 0.100 & $1.032^{* *}$ & 0.174 & 0.058 & 0.074 & $0.297^{* *}$ & 0.052 \\
\hline KOR & $0.910^{* *}$ & 0.158 & $1.574^{* *}$ & 0.377 & $0.176^{* *}$ & 0.060 & $0.253^{*}$ & 0.104 \\
\hline LKA & $0.435^{* *}$ & 0.158 & $0.975^{*}$ & 0.386 & -0.011 & 0.112 & -0.143 & 0.088 \\
\hline MAR & $0.606^{* *}$ & 0.133 & $0.719^{*}$ & 0.339 & -0.257 & 0.164 & 0.186 & 0.126 \\
\hline MEX & 0.033 & 0.236 & 1.143 & 0.620 & 0.562 & 0.290 & -0.823 & 0.481 \\
\hline NLD & $0.608^{* *}$ & 0.091 & $0.992^{* *}$ & 0.120 & $-0.257^{* *}$ & 0.084 & $0.119^{*}$ & 0.059 \\
\hline NOR & $0.786^{* *}$ & 0.215 & 0.529 & 0.430 & -0.318 & 0.226 & -0.009 & 0.097 \\
\hline NZL & $0.540^{* *}$ & 0.067 & $0.550^{* *}$ & 0.160 & -0.118 & 0.083 & 0.123 & 0.069 \\
\hline PAK & $0.630^{* *}$ & 0.174 & $1.839^{* *}$ & 0.285 & 0.301 & 0.216 & $-0.403^{*}$ & 0.166 \\
\hline PER & $0.476^{* *}$ & 0.157 & 1.367 & 0.684 & -0.030 & 0.190 & -0.054 & 0.119 \\
\hline PHL & 1.120 & 0.685 & 0.699 & 1.761 & 0.391 & 0.524 & $1.574^{* *}$ & 0.553 \\
\hline POL & $0.576^{* *}$ & 0.084 & $1.135^{* *}$ & 0.225 & $0.289^{* *}$ & 0.075 & $-0.248^{* *}$ & 0.062 \\
\hline PRT & $0.347^{*}$ & 0.139 & $1.125^{* *}$ & 0.139 & -0.050 & 0.130 & 0.098 & 0.083 \\
\hline RUS & $0.410^{* *}$ & 0.090 & 0.529 & 0.351 & -0.032 & 0.039 & $0.116^{*}$ & 0.051 \\
\hline SAU & $1.280^{* *}$ & 0.305 & 1.308 & 1.143 & $-0.374^{*}$ & 0.141 & $-0.424^{* *}$ & 0.103 \\
\hline SGP & $0.617^{* *}$ & 0.141 & 0.087 & 0.557 & $0.412^{* *}$ & 0.121 & -0.243 & 0.135 \\
\hline SWE & $0.418^{* *}$ & 0.106 & $0.587^{* *}$ & 0.139 & -0.137 & 0.074 & -0.188 & 0.112 \\
\hline THA & $0.597^{* *}$ & 0.146 & $0.722^{*}$ & 0.272 & $0.495^{* *}$ & 0.099 & $0.219^{*}$ & 0.094 \\
\hline TUN & $0.423^{* *}$ & 0.114 & $2.087^{* *}$ & 0.324 & $-0.742^{*}$ & 0.341 & -0.101 & 0.162 \\
\hline TUR & $0.534^{* *}$ & 0.047 & $1.324^{* *}$ & 0.157 & $0.132^{*}$ & 0.052 & $0.209^{* *}$ & 0.036 \\
\hline URY & $0.640^{* *}$ & 0.153 & 1.408 & 0.930 & 0.214 & 0.249 & $0.221^{*}$ & 0.096 \\
\hline USA & $0.622^{* *}$ & 0.076 & 0.001 & 0.132 & -0.059 & 0.070 & $0.159^{*}$ & 0.078 \\
\hline $\mathrm{ZAF}$ & $0.405^{* *}$ & 0.086 & $1.232^{*}$ & 0.505 & 0.101 & 0.212 & -0.074 & 0.111 \\
\hline
\end{tabular}

Note: ER is the estimated coefficient of the exchange rate and GDP is GDP of the importing country. LAG and LAG2 are the 1- and the 2-period lag coefficients of the exchange rate. 
Table 18: Estimates of long-run exchange rate elasticities for import quantities

\begin{tabular}{|c|c|c|c|c|c|c|c|c|}
\hline & \multicolumn{8}{|c|}{ Import Quantities } \\
\hline & ERC & $(\mathrm{SE})$ & GDP & (SE) & LAG.ERC & (SE) & LAG.2.ERC & $(\mathrm{SE})$ \\
\hline ARG & $-0.384^{* *}$ & 0.106 & $1.110^{* *}$ & 0.326 & 0.170 & 0.135 & 0.392 & 0.196 \\
\hline AUS & -0.131 & 0.166 & $1.669^{*}$ & 0.628 & $0.615^{* *}$ & 0.137 & -0.263 & 0.156 \\
\hline AUT & $-0.287^{* *}$ & 0.086 & $1.844^{* *}$ & 0.224 & $0.175^{*}$ & 0.079 & $0.365^{* *}$ & 0.074 \\
\hline BEL & $-0.623^{* *}$ & 0.102 & $1.153^{*}$ & 0.432 & -0.201 & 0.121 & $0.259^{* *}$ & 0.083 \\
\hline BRA & $-0.103^{*}$ & 0.049 & $1.726^{* *}$ & 0.390 & $-0.221^{* *}$ & 0.048 & -0.095 & .068 \\
\hline CAN & $-0.319^{* *}$ & 0.086 & 1.113 & 0.339 & 0.068 & 0.074 & -0.096 & 112 \\
\hline $\mathrm{CHE}$ & $-0.605^{*}$ & 0.251 & 0.355 & 0.8 & -0.3 & 0.302 & 0.464 & 465 \\
\hline CHL & -0.432 & 0.229 & $1.202^{* *}$ & 0.3 & -0.187 & 0.374 & $-0.195^{* *}$ & 065 \\
\hline $\mathrm{CHN}$ & -0.124 & 0.092 & 0.266 & 0.546 & $0.228^{* *}$ & 0.070 & 0.056 & 0.075 \\
\hline COL & $-1.054^{* *}$ & 0.170 & 1.145 & 1.124 & $-0.936^{* *}$ & 0.149 & -0.55 & 0.172 \\
\hline CRI & $-0.623^{*}$ & 0.286 & 1.062 & 0.717 & 1.019 & 0.814 & $-0.819^{*}$ & 0.394 \\
\hline CZE & $-0.589^{* *}$ & 0.066 & $0.977^{* *}$ & 0.310 & $-0.404^{* *}$ & 0.059 & 0.076 & 0.080 \\
\hline DEU & $-0.150^{*}$ & 0.058 & 1.291 & 0.188 & $0.104^{*}$ & 0.048 & .041 & 0.047 \\
\hline DNK & $-0.458^{* *}$ & 0.097 & $1.273^{* *}$ & 0.214 & 0.056 & 0.053 & 0.052 & 0.083 \\
\hline EGY & $-0.361^{*}$ & 0.144 & 0.853 & 0.805 & 0.066 & 0.098 & -0.061 & 0.161 \\
\hline ESP & $-0.268^{* *}$ & 0.074 & $1.124^{* *}$ & 0.245 & $0.166^{* *}$ & 0.058 & 0.063 & 0.041 \\
\hline FIN & $-0.278^{* *}$ & 0.088 & $1.194^{* *}$ & 0.307 & 0.002 & 0.086 & 0.21 & 0.088 \\
\hline FRA & $-0.292^{* *}$ & 0.098 & $2.027^{\circ}$ & 0.123 & 0.109 & 0.110 & 0.13 & 0.048 \\
\hline GBR & -0.106 & 0.070 & $1.377^{* *}$ & 0.252 & $0.381^{* *}$ & 0.047 & $0.162^{*}$ & 0.062 \\
\hline GRC & $-0.622^{*}$ & 0.285 & $1.710^{* *}$ & 0.342 & $0.5 \mathrm{~s}$ & 0.356 & -0.292 & 0.532 \\
\hline GTM & -0.254 & 0.320 & 1.725 & 0.927 & 0.203 & 0.241 & 0.0 & 0.261 \\
\hline HKG & -0.242 & 0.149 & 0.834 & 1.043 & -0.068 & 0.174 & $0.406^{*}$ & 0.162 \\
\hline [UN & -0.172 & 0.108 & $1.061^{* *}$ & 0.263 & $-0.295^{* *}$ & 0.083 & $-0.209 * *$ & 0.073 \\
\hline DN & -0.192 & 0.173 & $1.326^{* *}$ & 0.276 & $0.223^{*}$ & 0.084 & -0.102 & 0.082 \\
\hline ND & $-0.584^{* *}$ & 0.208 & 0.506 & 1.989 & 0.5 & 0.396 & 0.104 & 0.186 \\
\hline$R L$ & -0.544 & 0.347 & $2.020^{* *}$ & 0.312 & 0 & 0.164 & .16 & 0.163 \\
\hline R & $.598^{* *}$ & 0.135 & 1.294 & 0.925 & -0.2 & 0.17 & -0.0 & 0.133 \\
\hline ГА & $-0.252^{* *}$ & 0.047 & $1.270^{\circ}$ & 0.175 & .11 & 0.0 & 0.1 & 0.0 \\
\hline $\mathrm{PN}$ & -0.188 & 0.109 & 1.508 & 0.270 & 0.17 & 0.0 & & 0.070 \\
\hline OR & -0.109 & 0.048 & 1.436 & & & & & 0.072 \\
\hline LKA & -0.044 & 0.182 & & & & & & 11 \\
\hline IAR & $-0.704^{* *}$ & 0.202 & 1.398 & & -0. & 0.1 & & 0.088 \\
\hline MEX & $-1.145^{* *}$ & 0.133 & $1.610^{*}$ & 0.726 & $-1.182^{* *}$ & 0.156 & $0.785^{* *}$ & 0.077 \\
\hline NLD & $-0.497^{* *}$ & 0.122 & $1.866^{* *}$ & 0.23 & & 0.081 & & 0.080 \\
\hline NOR & -0.056 & 0.144 & 0.125 & 0.13 & 0.1 & 0.094 & & 0.170 \\
\hline NZL & -0.274 & 0.162 & 1.561 & 1.453 & $0.730^{* *}$ & 0.189 & -0.164 & 0.097 \\
\hline PAK & $-0.600^{*}$ & 0.294 & 1.015 & 2.471 & 0.447 & 0.238 & -0.058 & 0.190 \\
\hline PER & $-0.458^{*}$ & 0.204 & $0.965^{* *}$ & 0.273 & -0.069 & 0.161 & 0.152 & 0.140 \\
\hline PHL & -0.015 & 0.152 & 0.116 & 0.537 & 0.057 & 0.095 & -0.349 & 0.252 \\
\hline POL & $-0.454^{* *}$ & 0.050 & $0.702^{* *}$ & 0.261 & -0.075 & 0.053 & $0.146^{* *}$ & 0.040 \\
\hline PRT & $-0.277^{* *}$ & 0.081 & $1.312^{* *}$ & 0.227 & 0.014 & 0.125 & 0.100 & 0.076 \\
\hline RUS & -0.032 & 0.069 & $1.920^{* *}$ & 0.234 & $0.112^{*}$ & 0.044 & $-0.310^{* *}$ & 0.044 \\
\hline SAU & -0.053 & 0.347 & $0.542^{*}$ & 0.251 & 0.580 & 0.322 & -0.078 & 0.130 \\
\hline SGP & -0.036 & 0.141 & 0.077 & 0.237 & -0.111 & 0.099 & -0.007 & 0.103 \\
\hline SWE & -0.043 & 0.067 & $1.123^{* *}$ & 0.212 & 0.085 & 0.080 & $0.160^{* *}$ & 0.054 \\
\hline THA & -0.089 & 0.181 & $1.447^{* *}$ & 0.251 & -0.119 & 0.108 & $-0.387^{* *}$ & 0.093 \\
\hline TUN & $-0.388^{* *}$ & 0.128 & 0.086 & 0.260 & $0.231^{*}$ & 0.099 & 0.117 & 0.129 \\
\hline TUR & $-0.447 * *$ & 0.088 & $1.468^{* *}$ & 0.171 & $-0.476^{* *}$ & 0.064 & $-0.335^{* *}$ & 0.064 \\
\hline URY & -0.091 & 0.141 & 0.408 & 0.376 & $-0.405^{* *}$ & 0.096 & $-0.336^{* *}$ & 0.116 \\
\hline USA & -0.094 & 0.068 & $1.765^{* *}$ & 0.517 & $0.103^{* *}$ & 0.036 & 0.084 & 0.070 \\
\hline ZAF & -0.135 & 0.074 & 1.378 & 0.952 & $0.313^{* *}$ & 0.106 & -0.258 & 0.165 \\
\hline
\end{tabular}

Note: ER is the estimated coefficient of the exchange rate and GDP is GDP of the importing country. LAG and LAG2 are the 1- and the 2-period lag coefficients of the exchange rate. 